\title{
The antecedents of new R\&D collaborations with different partner types: On the dynamics of past R\&D collaboration and innovative performance
}

Citation for published version (APA):

Belderbos, R., Gilsing, V., Lokshin, B., Carree, M., \& Sastre, J. F. (2018). The antecedents of new R\&D collaborations with different partner types: On the dynamics of past R\&D collaboration and innovative performance . Long Range Planning, 51(2), 285-302. https://doi.org/10.1016/j.Irp.2017.10.002

Document status and date:

Published: 01/04/2018

DOI:

10.1016/j.Irp.2017.10.002

Document Version:

Publisher's PDF, also known as Version of record

Document license:

Taverne

Please check the document version of this publication:

- A submitted manuscript is the version of the article upon submission and before peer-review. There can be important differences between the submitted version and the official published version of record.

People interested in the research are advised to contact the author for the final version of the publication, or visit the DOI to the publisher's website.

- The final author version and the galley proof are versions of the publication after peer review.

- The final published version features the final layout of the paper including the volume, issue and page numbers.

Link to publication

\footnotetext{
General rights rights.

- You may freely distribute the URL identifying the publication in the public portal. please follow below link for the End User Agreement:

www.umlib.nl/taverne-license

Take down policy

If you believe that this document breaches copyright please contact us at:

repository@maastrichtuniversity.nl

providing details and we will investigate your claim.
}

Copyright and moral rights for the publications made accessible in the public portal are retained by the authors and/or other copyright owners and it is a condition of accessing publications that users recognise and abide by the legal requirements associated with these

- Users may download and print one copy of any publication from the public portal for the purpose of private study or research.

- You may not further distribute the material or use it for any profit-making activity or commercial gain

If the publication is distributed under the terms of Article 25fa of the Dutch Copyright Act, indicated by the "Taverne" license above, 


\title{
The antecedents of new R\&D collaborations with different partner types: On the dynamics of past R\&D collaboration and innovative performance
}

\author{
René Belderbos ${ }^{\mathrm{a}, \mathrm{b}, \mathrm{e}}$, Victor Gilsing ${ }^{\mathrm{d}, \mathrm{f}}$, Boris Lokshin ${ }^{\mathrm{b}}$, Martin Carree ${ }^{\mathrm{b},{ }^{*} \text {, }}$ \\ Juan Fernández Sastre ${ }^{\mathrm{c}}$ \\ ${ }^{a}$ Faculty of Economics and Business, Department of Managerial Economics, Strategy and Innovation, KU Leuven, Belgium \\ ${ }^{\mathrm{b}}$ School of Business and Economics, Department of Organisation and Strategy, Maastricht University, The Netherlands \\ c Facultad Latinoamericána de Ciencias Sociales, Ecuador \\ ${ }^{\mathrm{d}}$ ACED, Department of Management, University of Antwerp, Belgium \\ e UNU-MERIT, The Netherlands \\ ${ }^{\mathrm{f}}$ Free University Amsterdam, The Netherlands
}

\section{A R T I C L E I N F O}

\section{Article history:}

Available online 19 December 2017

\section{Keywords:}

R\&D

Collaboration

Alliances

Innovation

Partner types

\begin{abstract}
A B S T R A C T
We examine firms' propensity to adapt their R\&D collaboration portfolio by establishing new types of R\&D collaboration with different kinds of partners (suppliers, customers, competitors and universities \& public research institutions). We argue that existing R\&D collaboration with one of the two value chain partners (suppliers or customers) is associated with the formation of new R\&D collaboration with the other value chain partner to ensure temporal alignment in innovation within the value chain. In contrast, issues related to governance and unintended knowledge spillovers suggest that 'horizontal' $R \& D$ collaboration with competitors only spurs R\&D collaboration with other partner types if such competitor R\&D collaboration has been discontinued earlier ('delayed temporal alignment'). We posit that persistent prior R\&D collaboration with institutional partners is an antecedent to the establishment of new $R \& D$ collaboration with industrial partners, and that discontinuation of a particular type of R\&D collaboration is likely to lead to a restart of such $R \& D$ collaborative effort. Strong prior innovative performance is expected to increase the probability that firms establish R\&D collaborations with new partner types, except for R\&D collaboration with competitors, since the most innovative firms may fear leakage of proprietary knowledge to rivals. We find broad support for these predictions in a large panel of Spanish innovating firms (2004-2011). Our findings highlight that it is not just the configuration of $R \& D$ collaborations with existing partner types that predicts tie formation with new partner types, but also the intertemporal pattern of prior R\&D collaboration and managerial discretion provided by past innovation success.
\end{abstract}

(c) 2017 Elsevier Ltd. All rights reserved.

\footnotetext{
* Corresponding author.School of Business and Economics, Maastricht University, The Netherlands

E-mail address: m.carree@maastrichtuniversity.nl (M. Carree).
} 


\section{Introduction}

For firms in technology-intensive industries, external $R \& D$ collaboration for innovation has become a pervasive phenomenon. R\&D collaboration for innovation offers a number of substantive benefits, such as the possibility for mutual knowledge sharing, combining complementary skills with partners, scale economies in research, as well as the sharing of costs and risks (Ahuja, 2000a). A large body of literature has shown that R\&D collaboration can contribute to different performance outcomes such as innovation (e.g. Rothaermel and Deeds, 2004; Gilsing et al., 2008; Srivastava and Gnyawali, 2011; Belderbos et al., 2015), patenting (Gittelman and Kogut, 2003), organizational growth or failure (e.g. Mitsuhashi and Greve, 2009) and manufacturing procurement efficiency (Gulati and Sytch, 2007). A related literature has considered alliance portfolios - as the aggregate of all alliances of a focal firm - with a particular interest in portfolio diversity and its performance consequences (Rothaermel and Deeds, 2004; Faems et al., 2005; Heimeriks et al., 2009; Parmigiani and RiveraSantos, 2011; Wuyts et al., 2012; Lahiri and Narayanan, 2013; Jiang et al., 2010; Hashai et al., 2015; Jacob et al., 2013; Hagedoorn et al. 2017). This is in line with the dominant, yet static, view in most of the R\&D collaboration literature that emphasizes the stable value flowing from interfirm networks and R\&D collaboration portfolios (Wassmer, 2010; Tasselli et al., 2015; Jiang et al., 2010; Hashai et al., 2015).

However, as several success stories on R\&D collaboration for innovation have demonstrated, such as Procter and Gamble's connect and develop program, IBM's emerging business areas or Lego's open innovation strategy, companies regularly adapt their portfolio of R\&D collaborations in order to secure future competitiveness. This resonates with an emerging view in the literature that to ensure that $R \& D$ collaboration for innovation remains beneficial, firms need to adapt and renew their portfolio of partnerships on an ongoing basis (Powell et al., 1996; Ahuja et al., 2012). In particular, in technology-intensive environments, rapid technological change may render existing knowledge and skills obsolete, implying that current R\&D collaborations lose their value, and demanding adaptation of the R\&D collaboration portfolio (Koka et al., 2006).

Despite its importance, we still have only a limited understanding of how firms adapt their R\&D collaboration portfolio, and what the drivers of such adaptations are. The more widely studied outcome effects of a firms' R\&D collaboration portfolios remain only partially understood if we lack an appreciation of how portfolios are created and get adapted before giving rise to such outcomes in the first place (Ahuja et al., 2012; Tatarinowitz et al., 2016). The few studies on this topic have been theoretical (e.g. Koza and Lewin, 1998; Koka et al., 2006) or qualitative in nature (e.g. Lavie and Singh, 2011), and share a common emphasis on studying the evolution of an alliance portfolio under influence of, or in response to, contingencies and/ or changes in a firm's industry environment. While these studies have yielded some insightful characterizations of how R\&D collaboration portfolios evolve, they have examined the evolution of alliance portfolios by emphasizing how exogenous changes in the environment affect portfolio change.

In this paper, we aim to develop an agency-oriented understanding by considering the decisions to enter into new R\&D collaborations and therewith adapt the R\&D collaboration portfolio as a function of dynamic patterns of prior collaborations. Our focus is on a firm's portfolio of R\&D collaboration types, where we distinguish between customers and suppliers (vertical R\&D collaboration), competitors (horizontal $R \& D$ collaboration) and research institutions and universities (institutional $R \& D$ collaboration). ${ }^{1}$ We take a strategic perspective and move beyond the level of R\&D collaborations with individual partner firms, to R\&D collaboration decisions and portfolios at the level of collaboration types.

Conceptualizing R\&D portfolios through the lens of different partner types is relevant, as R\&D collaboration with different partner types gives rise to a potential for recombination that may spur the creation of innovations (Tidd et al., 2015; Faems et al., 2005; Duysters and Lokshin, 2011; Nieto and Santamaria, 2007; Belderbos et al., 2004a). To realize this recombination potential, a firm's standing R\&D collaborations may imply a sequence of R\&D collaborative activities where R\&D collaboration with one partner type, e.g. a university or a competitor, may lead to subsequent establishment of R\&D collaborations with other partner types, e.g. suppliers or customers. Hence, the adaptation of a firm's portfolio of R\&D collaborations with different partner types is likely to have antecedents in prior patterns of R\&D collaboration. This calls for a dynamic and integrative approach to analyze the establishment of new R\&D collaboration types and therewith the adaptation of R\&D portfolios - the approach that we take in this study.

Studying decisions to collaborate and adapt R\&D portfolios in an integrated manner is important as there is, as we will argue and show, strong heterogeneity in how existing collaborations with different partner types influence the formation of R\&D collaboration with new partner types. We argue that distinct patterns of relationships between the dynamics of prior R\&D collaboration (recently established, persistently pursued, or recently discontinued prior R\&D collaboration) and the establishment of R\&D collaboration with new partner types are likely to occur. This is because recombinatory search and accomplishing complementarity in $R \& D$ collaboration requires temporal alignment of R\&D collaborations. Hence, standing $R \& D$ collaborations with a specific partner type predict subsequent R\&D collaboration formation with another type, or the reestablishment of R\&D collaboration with the same partner type. We posit that salient differences can be expected in this regard between institutional (universities \& research institutes), vertical (buyer and supplier), and horizontal (competitor) R\&D collaboration. More specifically, we expect important benefits of inter-temporal alignment in R\&D collaboration with the

\footnotetext{
${ }^{1}$ We note that R\&D collaboration with universities \& public research institutes has also been referred to as 'upstream' R\&D collaboration (Bercovitz and Feldman, 2007; Rothaermel and Deeds, 2004). In the current study we reserve the term 'upstream' for firms that are situated upstream from the focal firm in the value chain: suppliers.
} 
two vertical chain partners (customers and suppliers) due to coordination advantages, and between university R\&D collaboration and $\mathrm{R} \& \mathrm{D}$ collaboration with industry partners at large due to knowledge complementarities. In contrast, temporal alignment between existing R\&D collaborations with competitors and new R\&D collaborations with other partner types may lead to undesirable knowledge spillovers, creating a different dynamic and leading to delayed adaptation of the R\&D collaboration portfolio through the establishment of $R \& D$ collaboration with new partner types.

As a second antecedent of adaptation of the R\&D collaboration portfolio, we consider a firm's prior innovation performance. Whereas the literature has demonstrated that R\&D collaboration contributes to innovation performance (Ahuja, 2000b; Gilsing et al., 2008), how such performance affects a firm's propensity to engage in future R\&D collaboration has remained underexposed (Phelps et al., 2012). While one may expect a positive interrelationship between prior performance and the formation of R\&D collaborations because firms become more attractive as R\&D collaboration partners in case of past innovation success, successful firms may at the same time find it less necessary to engage in R\&D collaboration as they have demonstrated strong internal innovation capabilities (Ahuja, 2000a; Phelps et al., 2012). Furthermore, firms with a strong innovation performance may fear that R\&D collaboration could lead to involuntary knowledge dissipation to partner firms, which may hurt their innovation performance in the future. We argue that these considerations get different weights depending on the type of partner the firm seeks to establish R\&D collaborations with, with major differences between competitor R\&D collaboration and R\&D collaborations with other partner types.

Empirically, we draw on panel data consisting of a large sample of Spanish innovating firms (2004-2011) and estimate multivariate probit models of the yearly formation of R\&D collaborations with a new partner type. We note one limitation and caveat up-front: our data do not pertain to $R \& D$ collaborations with individual partners, but to the start, cessation or continuation of $R \& D$ collaboration with different partner types. Hence, our theory and analysis focus on the broader strategic rationale for the dynamics of $R \& D$ collaboration patterns and remain agnostic of the absolute number of $R \& D$ collaborations with individual partners of each type.

\section{Theory and hypotheses}

Internal sources of technology development are often inadequate to cope with the increasing environmental complexity and speed of technological change (Barney, 1991; Mahoney and Pandian, 1992; Peteraf, 1993). Firms therefore rely on R\&D collaborations with partners to access external sources of knowledge that may account for a substantial share of complementary inputs necessary for the development of successful innovations (Chesbrough et al., 2014; Fey and Birkinshaw, 2005). Recent studies have considered potential complementarities of different alliance types that serve different purposes, such as alliances for shaping environments, adapting environments or stabilizing environments (Hoffman, 2007), alliances for complementarity and/or compatibility (Mistsuhasi and Greve, 2009), and alliance (networks) for exploration or exploitation (Koza and Lewin, 1998; Rothaermel and Deeds, 2006; Colombo et al., 2006; Gilsing and Nooteboom, 2006).

Diversity in partner types can bring innovation performance benefits if different partner types complement the focal firm's resources and capabilities (Duysters and Lokshin, 2011; Faems et al., 2005; Nieto and Santamaria, 2007; Belderbos et al., 2004a). The potential advantages of combining R\&D collaboration with different partner types suggest that firms' existing R\&D collaboration portfolios can be an important antecedent of new R\&D collaborative tie formation (e.g. Lavie et al., 2011), as reaping the benefits of complementarity is likely to require temporal alignment between $R \& D$ collaborations.

Most of the literature has focused on R\&D collaborations with different individual partners - 'with whom' to ally - while ignoring differences among partner types. A number of prior studies focused on a specific type of R\&D collaboration, such as horizontal R\&D collaboration with competitors (Ahuja, 2000a), vertical R\&D collaboration between customers and suppliers (Gulati and Sytch, 2007), or R\&D collaboration with universities (Gittelman and Kogut, 2003; Bercovitz and Feldman, 2007). Rothermael and Deeds (2004) is closest to our study in their focus on how one type of alliances (specifically exploration alliances with a focus on R\&D and drug discovery) systematically predicts the formation of another type of alliances (exploitation alliances) - a relationship that is mediated by the number of products in development. However, neither of these prior studies systematically considered relationships between horizontal, vertical and institutional collaboration (Parmigiani and Rivera-Santos, 2011). To address this issue, we examine the dynamic interrelationship between R\&D collaborations with such different partner types, and do so across manufacturing industries rather than for a specific industry such as the biopharmaceutical industry (e.g. Rothaermel and Deeds, 2004).

Below we develop hypotheses focusing on such dynamic interrelationships. More specifically, we will examine the following three antecedents of the formation of R\&D collaboration with a new partner type: 1 ) the role of recent, persistent, and prior discontinued R\&D collaboration with other partner types (temporal alignment in R\&D collaboration across partner types), 2) discontinued R\&D collaboration as an antecedent of the re-establishment of R\&D collaboration with that same partner type, and 3) prior innovative performance as an antecedent of the formation of R\&D collaboration with a new partner type. Considering these antecedents helps to develop a better understanding of how firms' R\&D collaboration portfolio diversity is created in a dynamic context. This portfolio development will carry consequences for firm performance, which in turn may affect the propensity to form new R\&D collaborative ties (Ahuja, 2000a). In order to account for this recursive process, it is important to consider how a firm's prior innovation performance affects its propensity to adapt its portfolio of R\&D collaboration types. Table 1 illustrates the focus of our theory development and hypotheses: the independent variables and their predicted effects on R\&D collaboration formation with a new partner type. 
Table 1

Framework and hypotheses.

\begin{tabular}{|c|c|c|c|c|}
\hline \multirow[t]{2}{*}{ Prior collaboration with } & \multicolumn{4}{|c|}{ Starting R\&D collaboration with a new partner type: } \\
\hline & Suppliers & Customers & Competitors & Institutes \\
\hline \multicolumn{5}{|l|}{ Suppliers } \\
\hline Recent & - & $\mathrm{H} 1 \mathrm{~b}(+)$ & & \\
\hline Persistent & - & $\mathrm{H} 1 \mathrm{~b}(+)$ & & \\
\hline Recently discontinued & $\mathrm{H} 4(+)$ & $\mathrm{H} 1 \mathrm{~b}(\mathrm{n})$ & & \\
\hline \multicolumn{5}{|l|}{ Customers } \\
\hline Recent & H1a $(+)$ & - & & \\
\hline Persistent & $\mathrm{H} 1 \mathrm{a}(+)$ & - & & \\
\hline Recently discontinued & H1a (n) & $\mathrm{H} 4(+)$ & & \\
\hline \multicolumn{5}{|l|}{ Competitors } \\
\hline Recent & $\mathrm{H} 2(\mathrm{n})$ & $\mathrm{H} 2(\mathrm{n})$ & - & $\mathrm{H} 2(\mathrm{n})$ \\
\hline Persistent & $\mathrm{H} 2(\mathrm{n})$ & $\mathrm{H} 2(\mathrm{n})$ & - & $\mathrm{H} 2(\mathrm{n})$ \\
\hline Recently discontinued & $\mathrm{H} 2(+)$ & $\mathrm{H} 2(+)$ & $\mathrm{H} 4(+)$ & $\mathrm{H} 2(+)$ \\
\hline \multicolumn{5}{|l|}{ Institutes } \\
\hline Recent & & & & - \\
\hline Persistent & H3 (+) & H3 (+) & H3 (+) & - \\
\hline Recently discontinued & & & & $\mathrm{H} 4(+)$ \\
\hline Prior innovation performance & $\mathrm{H} 5 \mathrm{a}(+)$ & H5b (inverted-U) & $\mathrm{H} 5 \mathrm{a}(+)$ & $\mathrm{H} 5 \mathrm{a}(+)$ \\
\hline
\end{tabular}

Notes: hypothesized relationship in parentheses; $\mathrm{n}=$ negligible; $-=$ not applicable.

New vertical $R \& D$ collaboration spanning the value chain

There are several reasons why $R \& D$ collaboration with one partner type can be an antecedent of the formation of new $R \& D$ collaborative R\&D ties with other partner types. These reasons relate to potential synergies such as complementary skills of the different partner types as well as coordination advantages in product and process development. This implies that the probability of forming $R \& D$ collaborative $R \& D$ ties with a new partner type depends on the partner types with which the firm already collaborates. The specific temporal pattern of prior R\&D collaboration with a partner type (recently formed, persistent, or discontinued) is expected affect this relationship.

There are compelling arguments to expect a particularly strong relationship between supplier and customer R\&D collaboration (Belderbos et al., 2012). Vertical R\&D collaboration with suppliers or customers implies the bridging of two value chain activities. By its nature, a value chain entails a highly systemic division of labor where changes in one value chain activity may have far-reaching implications for adjacent value chain activity - upstream and/or downstream. As a consequence, new product innovations or process improvements need to be well coordinated in order to mitigate risks of (major) inconsistencies across two or more value steps and to ensure their timely commercialization and/or implementation (DiezVial, 2007; Littler and Leverick, 1995). Vertical R\&D collaboration may also facilitate the reduction or elimination of operational inefficiencies along a value chain such as, for example, those resulting from 'bullwhip' effects due to demand variability (Metters, 1997; Lee et al., 1997; Gulati and Sytch, 2007). R\&D collaboration with both types of chain partners enables firms to speedily commercialize new product innovations and to accomplish process improvements in both an efficient and effective way (Choi and Hartely, 1996; Fisher, 1997; Childerhouse et al., 2002; Rosenzweig et al., 2003). The operations management literature has suggested that it is this continuous engagement in vertical, value chain spanning, collaboration with suppliers and customers that achieves superior performance (Narasimhan and Jayaram, 1998; Vickery et al., 2003; Frohlich and Westbork, 2001; Rosenzweig et al., 2003; Roy and Whelan, 1992).

Accomplishing these performance objectives induces a need for firms to act in tune and suggests the need for a temporal alignment in R\&D collaboration with suppliers and customers. This temporal alignment may be accomplished in both directions, i.e. aligning existing supplier $R \& D$ collaboration with customer R\&D collaboration, and vice versa. To the extent that R\&D collaboration with suppliers is aimed at the creation of new innovations, it introduces a need for a focal firm to test the effects of market introduction with customers. Introducing innovations can be risky or costly for customers as it may require adaptations to their existing routines and practices (Christensen and Bower, 1996). R\&D collaboration with a focal firm may be effective for customers since it will allow them to test and experiment with a new innovation before deciding to adopt it (Von Hippel, 1988; Tidd et al., 2015). Hence, current R\&D collaboration with suppliers may naturally lead a focal firm to augment its R\&D collaboration portfolio by starting R\&D collaboration with customers.

Customer R\&D collaboration in turn may provide new insights for further fine-tuning and improving the innovation, or in case of R\&D collaboration with lead-users it may provide fresh ideas for new, future innovations (Von Hippel, 1988). Both situations will induce a need to initiate $R \& D$ collaboration with suppliers to develop these ideas further into improved or novel innovations. In general, innovations in the vertical R\&D collaboration process benefit from a relatively speedy and wellcoordinated process that requires R\&D collaboration with suppliers and with customers. This implies that such R\&D collaborations with suppliers and customers are preferably not pursued in isolation. If a firm engages in active (persistent or recent) $R \& D$ collaboration with one type of partner, the formation of R\&D collaboration with the other partner type is likely to follow.

In addition to the effectiveness of innovation in the value chain, there also is a resource scarcity logic that reinforces the need for temporal alignment between customer and supplier R\&D collaboration. Firms face resource constraints that will 
limit the resources they can allocate to external R\&D collaboration activities (Heimeriks et al., 2009). R\&D collaboration with one partner type, e.g. suppliers, can consume ample resources and managerial attention, which will limit the room for simultaneous R\&D collaboration with another partner type, e.g. customers. As a consequence, resource constraints can reinforce the need for consecutive supplier and customer $R \& D$ collaboration to coordinate vertical $R \& D$ collaboration along the value chain.

The above arguments suggests a symmetric pattern in which existing R\&D collaboration with suppliers (customers) will increase the propensity of firms to adapt the $R \& D$ collaboration portfolio by starting R\&D collaboration with customers (suppliers). Since firms are expected to seek temporal alignment between existing R\&D collaborations and the establishment of new R\&D collaborations while alignment cannot be obtained if firms have previously discontinued their R\&D collaboration with suppliers or customers, alignment is not likely to be a consideration for previously discontinued collaborative R\&D ties with customers, or suppliers. This leads to the following hypotheses:

Hypothesis 1a. Existing (recently established and persistent) $R \& D$ collaboration with customers, rather than prior discontinued $R \& D$ collaboration with customers, are positively associated with a firm's propensity to augment its portfolio of R\&D collaboration types by newly establishing R\&D collaboration with suppliers.

Hypothesis 1b. Existing (recently established and persistent) $R \& D$ collaboration with suppliers, rather than prior discontinued $R \& D$ collaboration with suppliers, is positively associated with a firm's propensity to augment its portfolio of R\&D collaboration types by newly establishing $R \& D$ collaboration with customers.

Prior (discontinued) $R \& D$ collaboration with competitors and the establishment of new $R \& D$ collaborations with other partner types

We argue that the influence of prior R\&D collaboration with horizontal partners (competitors) on the establishment of R\&D collaboration with new partner types shows a pattern that contrasts with that of vertical R\&D collaboration. Whereas vertical R\&D collaboration is generally considered to be well suited for enhancing existing competences and optimizing an established value chain (Brown and Eisenhardt, 1995), horizontal R\&D collaborations are generally considered to be better suited for the creation of new, state-of-the-art technology (Tidd et al., 2015). Horizontal R\&D collaboration tends to focus on pre-competitive development of far-from-market technology with wide(r) application potential (Teece, 1980; Hagedoorn, 2002; Belderbos et al., 2012; Tether, 2002). This may form the basis for a focal firm's future competitive advantage in noncore domains, securing continuity in the long term. Prior studies on the performance effects of R\&D collaboration with different partner types have confirmed that R\&D collaboration with competitors is often most effective for the generation of new-to-the-market products, while vertical R\&D collaboration with suppliers and customers tend to impact on productivity growth, product and process improvements (Belderbos et al., 2004a; Faems et al., 2005).

Horizontal technology-based R\&D collaboration may provide firms with access to scarce, external expertise on promising new technologies, and may allow for the exchange of knowledge between partners that stimulate learning and facilitate its further recombination (Ahuja, 2000b). Such recombinatory efforts may lead to the creation of technologies with a high novelty and value, which may induce $R \& D$ collaboration with other partner types in two different ways. First, discovery of new technology can induce a quest for further exploration and deepening of the new domain that leads to institutional R\&D collaboration with universities \& research institutes (Baba et al., 2009). Second, firms are likely to embark on exploitation efforts aimed at the commercialization and/or implementation of the newly created technology, which may involve vertical R\&D collaboration with suppliers and/or customers (Choi and Hartely, 1996; Fisher, 1997; Childerhouse et al., 2002; Rosenzweig et al., 2003; Tidd et al., 2015).

R\&D collaboration with competitors and the potentially associated new-to-the market technology and innovations also carries particular risks when following up on this in R\&D collaborations with other partner types. Due to comparable knowledge bases and competences, competitors may have a greater capacity for absorption and appropriation of each other's core knowledge and expertise, which eases the (undesirable) flow of spillovers and creates a temptation for free-ridership (Park and Russo, 1996; Gilsing and Nooteboom, 2006). This implies that engagement in both horizontal and vertical R\&D collaboration increases the likelihood that knowledge developed with customers, suppliers and/or universities \& research institutes, spills over to horizontal partners, conform the idea of indirect ties (Ahuja, 2000b) and second-hand brokerage (Burt, 2004). Since horizontal partners are likely to figure as a firm's competitors in downstream markets, such knowledge spillovers may directly erode its competitive advantage (Ahuja, 2000a). In particular, if R\&D collaboration is in the focal firm's core domains, this may severely damage its competitiveness and threaten its future profitability.

Thus, although from an innovation perspective the potential complementarity between competitor R\&D collaboration and $R \& D$ collaboration with other partner types is attractive, a governance perspective on R\&D collaboration suggests important risks and drawbacks of close temporal alignment between horizontal and vertical R\&D collaboration. We argue that these perspectives can be reconciled through delayed alignment. The governance risks are foremost an issue if the two types of R\&D collaboration overlap in time, such that the focal firm connects competitors and vertical or institutional partners. At the same time, positive effects from an innovation perspective and reaping the benefits of complementarity may still be possible by combining horizontal with vertical or institutional R\&D collaboration in a more consecutive manner. This suggests that discovery and development of next-generation technology with competitors may induce delayed institutional R\&D collaboration with universities \& research institutes for further deepening and search, or 
induce later vertical R\&D collaboration with customers and suppliers in view of implementation and commercialization needs.

Overall, these arguments suggest that if horizontal $R \& D$ collaboration precedes institutional R\&D collaboration with universities \& public research institutes or precedes vertical R\&D collaboration with suppliers and customers, governance risks related to overlapping $R \& D$ collaborations can be reduced, without sacrificing the combinatory benefits. Hence, the probability that a firm adds vertical and institutional R\&D collaboration to its R\&D collaboration portfolio is expected to be higher if the firm has engaged in horizontal $R \& D$ collaboration, but only with a sufficient lag - i.e. when R\&D collaboration with competitors has been prior discontinued. This leads to the following Hypothesis:

Hypothesis 2. Prior discontinued $R \& D$ collaboration with competitors, rather than existing R\&D collaboration with competitors, is positively associated with a firm's propensity to augment its portfolio of $R \& D$ collaboration types by newly establishing R\&D collaboration with other partner types.

Existing institutional $R \& D$ collaboration and the establishment of $R \& D$ collaboration with other partner types

Universities \& public research institutes generally are a key source of new, state-of-the-art knowledge (Cockburn and Henderson, 1998; Zucker et al., 2002; Bercowitz and Feldman, 2007; Cassiman et al., 2009; Belderbos et al., 2016). Knowledge as developed in universities is of a more generic nature, tends to be further away from commercialization, and typically contributes to the generation of new ideas for industrial R\&D. Universities can also play a key role in contributing to the completion of existing R\&D projects and technical problem solving in manufacturing processes (Cohen et al., 2002). In addition, R\&D collaboration with universities in general, and with prestigious universities in particular, may elevate a firm's status (Gregorio and Shane, 2003), increasing its attractiveness to other firms as a R\&D collaboration partner. Here it is important that the firm is perceived as a reliable and stable partner and engages in such R\&D collaboration persistently.

Although new scientific knowledge gets disseminated through publications, an important part of it is non-codified and can only be exchanged through close interaction between individuals within teams of university and firm scientists (Zucker et al., 2002; Cassiman et al., 2009). This tacit and complex nature of scientific knowledge induces a need for longer term relationships with universities in order to get more deeply involved in, and familiar with, scientific research and the institutional norms governing knowledge creation at universities. Persistent R\&D collaboration with universities can enable firms to better understand advances in fundamental research and evaluate its quality and usefulness. If a firm collaborates with universities \& public research institutes on a persistent basis, it will be able to develop a deeper understanding of the fundamental principles of key phenomena under study, increasing the likelihood of the discovery of novel causal relationships that may result from such R\&D collaboration (Bercowitz and Feldman, 2007). Prior research suggests that effective R\&D collaboration with universities can subsequently allow firms to apply scientific insights to their applied R\&D projects, but this process requires endurance and time before it enhances R\&D productivity (Cockburn and Henderson, 1998; Zucker et al., 2002).

The more generic nature of knowledge developed in R\&D collaboration with universities and its potential for generating new ideas and enhancing applied research helps firms to assess which trajectories in applied research may probably become dead-ends and which will be the most promising opportunities (Fleming and Sorenson, 2004). This creates incentives for firms for subsequent R\&D collaboration with different industrial partners to exploit such opportunities (Segarra-Blasco and Arauzi-Carod, 2008). Knowledge generated in R\&D collaboration with universities may bring new insights that may open up entire new markets or market segments (Tether, 2002; Monjon and Waelbroeck, 2003; Leiponen, 2001; Veugelers and Cassiman, 2005) and may bring knowledge and new ideas for both process and product innovations (Monjon and Waelbroeck, 2003; Belderbos et al., 2004a; Faems et al., 2005). Capabilities acquired during persistent R\&D collaboration with universities will aid firms in the effective selection and focus of those R\&D collaborations with customers, suppliers, or competitors in the commercialization of new technologies and the implementation of improved or new processes (Arranz and Arroyabe, 2008).

These arguments suggest that firms with prior persistent engagement in R\&D collaboration with universities \& research institutes have both the incentives and opportunities to start R\&D collaboration with new industrial partner types. This leads to the following Hypothesis:

Hypothesis 3. Persistent involvement in $R \& D$ collaboration with universities \& research institutes is positively associated with a firm's propensity to augment its portfolio of $R \& D$ collaboration types by newly establishing $R \& D$ collaboration with industrial partners (suppliers, customers, competitors).

Discontinued $R \& D$ collaboration and the propensity to renew $R \& D$ collaboration with the same partner type

Prior research on the dynamics of R\&D collaboration has focused primarily on alliance termination, but less so on the propensity to restart $R \& D$ collaboration. Unsuccessful $R \& D$ collaborations are a frequent feature of inter-firm $R \& D$ collaboration and unsuccessful $R \& D$ collaboration rates of 30-50\% are common findings in the literature (e.g. Bleeke and Ernst, 1991; Harrigan, 1988; Killing, 1988; Lokshin et al., 2011). This while persistent R\&D collaboration is likely to provide the strongest benefits in terms of innovation success (e.g. Belderbos et al., 2015). 
Although the termination of $R \& D$ collaboration is not always the result of malfunctioning of the R\&D collaboration but may also signal the completion of the R\&D collaborative project when goals have been accomplished, the evidence suggests that discontinued $R \& D$ collaboration often implies that $R \& D$ collaborative efforts have met with coordination problems (Lhuillery and Pfister, 2009). R\&D collaboration implies the coordination of activities between two independent organizations that may share a need for resource exchange but will also differ in a number of ways. To the extent that partners differ substantially in terms of core activities, organizational culture, strategic aims and/or what they aim to achieve through R\&D collaboration, coordination becomes difficult and R\&D collaboration failure is more likely (Parkhe, 1993). Therefore, common problems are the pursuit of self-interest at the expense of the partner (Gulati, 1995), power imbalances between partners due to asymmetry in resource quality (Kogut, 1989), and technological uncertainty leading to unexpected outcomes that may be incongruent with the original purpose of the R\&D collaboration. These problems can occur in R\&D collaboration with each partner type.

Notwithstanding these general reasons why individual R\&D collaboration may fail, the general benefits of R\&D collaboration with different partner types remain of strategic significance for innovating firms. Key benefits of R\&D collaboration with any partner type are the sharing of costs and risks of $R \& D$, access to unique and novel expertise regarding new technology and/or markets as well as the potential for resource complementarity that yields opportunities for recombination (Hagedoorn, 1993; Ahuja, 2000a).

Hence, if a given individual $R \& D$ collaboration with a specific partner type fails because the specific firm or institution is no longer the best match or willing to continue, and this leads to the discontinuation of R\&D collaboration with that partner type, innovation needs will request a tying up to a new individual partner of the same type to address the same strategic need. It follows that discontinued $R \& D$ collaboration with a type of partner is likely to lead to a subsequent restarting of $R \& D$ collaboration with that same type of partner. We hypothesize:

Hypothesis 4. Prior discontinued $R \& D$ collaboration with a partner type is positively associated with a firm's propensity to augment its portfolio of $R \& D$ collaboration types again, by re-establishing $R \& D$ collaboration with that partner type.

Past innovative success and the propensity to start new $R \& D$ collaborations: horizontal partners vs. other partner types

While R\&D collaboration is often crucial for innovation success (Hagedoorn, 1993, 2002; Duysters and Lokshin, 2011; Rowley et al., 2000), innovation success in turn may spur further R\&D collaboration. Firms that have established themselves as highly innovative will be considered as technologically capable and desirable as R\&D collaboration partners (Stuart et al., 1999). Ahuja (2000a) argues that the propensity to establish R\&D collaborations is determined by both 'inducements' and 'opportunities', with differences in such firm-specific inducements and opportunities accounting for the uneven participation in inter-firm (R\&D) collaborations. Successfully innovating firms may have greater opportunities to engage in R\&D collaboration and are more attractive partners for joint technology development with suppliers, customers, competitors or universities. On the other hand, by participating in inter-firm R\&D collaboration, the more successful innovative firms face a danger of involuntary dissipation of their knowledge, which can lead to a weakening of their competitive advantage (Mitchell and Singh, 1992; Littler and Leverick, 1995; Molina-Morales et al., 2011). Moreover, the most successful innovators will have relatively less to learn from R\&D collaboration partners. These considerations suggest that highly successful innovators may benefit relatively less from R\&D collaboration (Khanna et al., 1998).

There are strong reasons to believe that the risk of knowledge dissipation is greatest in R\&D collaborations with competitors (Blomqvist et al., 2005; Hurmelinna-Laukkanen and Olander, 2014; Belderbos et al., 2004a,b). In general, the probability of opportunistic behavior by partners in R\&D collaboration is reduced through mutual dependence (Gulati and Sytch, 2007), and the expectation of durability provides the confidence that investments in the R\&D collaborative projects can indeed be recouped (Gilsing and Nooteboom, 2006). This mutual dependence is however likely to be relatively weak in the case of competitor R\&D collaboration. Here competition policy often dictates pre-competitive R\&D collaboration. Firms collaborate in the development of technology but subsequently compete in the product market in the commercialization phase. In addition, horizontal partners may be eager to collaborate with highly innovative firms because they see a potential to learn disproportionately from the R\&D collaboration (Ahuja, 2000a). This increases the risk for innovation leaders that their partners engage in freeriding to benefit in the commercialization stage.

The above concerns are mitigated in R\&D collaborations with vertical partners and with universities \& research institutions. R\&D collaboration with vertical partners is characterized by more durable, mutual dependence including commercialization and continuous improvements, while inputs of upstream and downstream partners may remain a necessity also for innovation leaders to sustain their lead (Tidd et al., 2015; Gulati and Sytch, 2007). Highly innovative firms may also have more opportunities and incentives to establish R\&D collaborations with universities as their strong innovation capacity enables them to understand and apply state-of-the-art, academic expertise (e.g. Cassiman et al., 2009). Risks of spillovers and misappropriation are limited as university and public research institutions generally do not have commercialization objectives.

These arguments suggest that innovative performance may provide opportunities and inducements for vertical R\&D collaboration and for R\&D collaboration with universities \& research institutes. However, for competitor R\&D collaboration the situation differs. At a low(er) level of innovation performance, R\&D collaboration with competitors may be attractive as there is room to learn from others and relatively little to lose, suggesting a positive influence on new collaboration formation. 
At higher levels of innovation performance, however, knowledge dissipation risks become greater, while inducements are reduced as the potential to learn from others diminishes. For the most innovative firms a resulting negative 'inducement' to engage in R\&D collaboration (Ahuja, 2000a) is likely to outweigh the greater opportunities to engage in R\&D collaboration with competitors, suggesting a negative influence on collaboration formation.

Overall, these arguments apply a positive association between prior innovative performance and R\&D collaboration with vertical and institutional partners, while a positive relationship with competitor R\&D collaboration is likely to diminish and eventually become negative with higher levels of prior innovative performance. This leads to the following hypotheses:

Hypothesis 5a. Past innovative performance is positively associated with a firm's propensity to augment its portfolio of R\&D collaboration types by newly establishing $R \& D$ collaboration with customers, suppliers, and universities \& research institutes.

Hypothesis 5b. Past innovative performance has an inverted U-shaped association with a firm's propensity to augment its portfolio of $R \& D$ collaboration types by newly establishing $R \& D$ collaboration with competitors.

\section{Data and methods}

Data and sample

The empirical analysis uses data from the Spanish Survey of Technological Innovation PITEC (Panel de Innovación Tecnológica). The survey is carried out by the Spanish National Statistics Institute (INE), the Spanish Foundation for Science and Technology (FECYT) and the Foundation for Technological Innovation (COTEC). The PITEC dataset is well-suited for the investigation of our research questions and has several advantages that we exploit in our research. The first advantage is that the survey contains information on firms' innovation activities, including questions on R\&D collaboration, and is conducted annually starting from 2004 onwards. This feature is important for our analysis of specific patterns of inter-temporal interrelationships among R\&D collaborative agreements. Second, the PITEC survey follows guidelines in the Oslo Manual (OECD, 2005) and is therefore comparable to the Community Innovation Survey (CIS) that is conducted every two years on behalf of Eurostat and constitutes a main survey instrument to garner harmonized data on firm innovation activities in the EU. The third advantage is that PITEC is designed as a panel data survey, with high compatibility in firm sampling across the different waves, which helps mitigate problems of attrition and selection, and allows the use of lagged explanatory variables in the analysis. Fourth, the survey covers firms operating in all sectors of the Spanish economy according to the CNAE-93 classification and is representative of the population of firms engaged in innovation activities. ${ }^{2}$

The PITEC questionnaire has a multi-layer structure. Only those firms that report to be engaged in innovative activities are asked to complete the entire questionnaire and are the focus of our analysis. Apart from this selectivity - we explain how we deal with it in the methods section - most firms are observed for the entire period, and the panel is strongly balanced in nature. Our analysis focuses on firms active in manufacturing industries and requires that we observe a firm at least three consecutive years to establish inter-temporal patterns of past R\&D collaboration and the relationship with newly established $R \& D$ collaborations. The dependent variables are measured in year $t$ and we use information from the previous survey(s) conducted in year $\mathrm{t}-1$ and in year $\mathrm{t}-2$ to construct the focal independent variables. This approach resulted in a sample covering 6055 firms, for which we jointly have 26,608 observations for the years 2006-2011.

\section{Measures}

Dependent variable: $R \& D$ collaboration with a new partner type

To construct the dependent variable(s), we use answers to the questions from the PITEC surveys pertaining to a firm's R\&D collaboration with customers, suppliers, competitors and universities \& research institutes. Each of the four dependent variables is a binary (yes/no) indicator of whether a firm established new R\&D collaboration in a year with respectively, suppliers, customers, competitors, and universities \& research institutions. Since we focus on changes in portfolios or $R \& D$ collaborations with different partner types and examine newly formed R\&D collaboration with these specific partner types, this implies that we restrict the analysis to those firms that had no existing R\&D collaboration with the specific partner type in the year before. The dependent variable new customer R\&D collaboration, for instance, takes the value 1 (else zero) if a firm reported engagement in R\&D collaboration with a customer in the survey of year $t$ but not in the survey of year $t-1$. The indicators of new supplier, new competitor and new university R\&D collaboration are constructed analogously.

\section{Prior $R \& D$ collaboration}

In our analysis we differentiate between each of the partner types among R\&D collaborations that started in year $t-1$ (recently established or, recent), $\mathrm{R} \& \mathrm{D}$ collaboration agreements that started in year $t-2$ and continued in year $t-1$ (persistent) and R\&D collaboration that started in year $t-2$ but was discontinued in year $t-1$ (prior discontinued). These

\footnotetext{
${ }^{2}$ A more detailed description of the data and sampling can be found on the FECYT web site: http://icono.fecyt.es/pitec/Paginas/por que.aspx.
} 
different types and patterns of prior R\&D collaboration (in year $t-1$ and in year $t-2$ ) are examined as antecedents of the establishment of R\&D collaborations with new partner types in year $t$. For instance, recent $R \& D$ collaboration with customers takes the value 1 (else zero) if a firm was cooperating with customers in year $t-1$ but not in year $t-2$. Persistent involvement in $R \& D$ collaboration with customers takes the value 1 (else zero) if a firm reports $R \& D$ collaboration with customers in year $t-1$ and $t-2$, i.e. in two consecutive prior surveys. Prior discontinued $R \& D$ collaboration with customers takes the value 1 if a firm was engaged in R\&D collaboration with customers in the survey of $t-2$ but not in the survey in $t-1$. Recent, persistent, and prior discontinued $R \& D$ collaboration with suppliers, competitors and universities \& research institutions are constructed analogously. Hypotheses 1-4 predict various relationships between these types of existing R\&D collaborations with different partner types and firms' propensity to augment their portfolio with other R\&D partner types. ${ }^{3}$

Past innovative performance is defined as the logarithm of sales from products that are new to the market divided by the total number of employees (cf. Belderbos et al., 2004a). We define this performance measure in deviation from the (2-digit) industry mean to account for the fact that the pace of product renewal and technological change varies across industries, and that macroeconomic shocks may affect industries differently. ${ }^{4}$ Sales of products new to the market is an often used indicator of (successful) innovations (e.g. Faems et al., 2005; Leiponen and Helfat, 2011). New to the market products can be seen as more 'radical' in the sense that products are not just new to the firm, but also putting the firm ahead in its industry. The scaling by the number of employees to arrive at a productivity measure assures that the performance measure is not sizerelated or right censored and that the efficiency of the innovative process (where R\&D collaboration will play a key role) is taken into account. ${ }^{5}$ We allow for non-linear relationships between past innovative performance and the propensity to establish R\&D collaborations with new partner types by including the squared term of the past innovative performance in our model.

\section{Control variables}

We include $R \& D$ intensity as a key input into the innovation process and as a source of absorptive capacity benefitting R\&D collaboration. We take the broadest definition of $R \& D$ available in the innovation survey that includes intramural $R \& D$, expenditures on external R\&D (acquisition of technologies, R\&D contracting) and expenditures on marketing and design of innovations.

Firm size is measured as the logarithm of the firm's number of employees. Larger firms are more likely to be engaged in broader technology development activities and are more likely to require R\&D collaboration with different partner types (Freel, 2003; Bayona et al., 2001; Becker and Dietz, 2004).

We control for the export intensity of the firm because firms have been found to 'learn by exporting' by operating in international markets, gaining access to technical expertise and ideas from foreign customers and competitors. This process may involve establishing R\&D collaborations with foreign firms to have broader access to locally embedded knowledge (e.g. Woerter and Roper, 2010; Salomon and Shaver, 2005).

The variable resource constraints captures factors hampering the innovation process of a firm, potentially pushing the firm to engage in $R \& D$ collaboration. Extant literature suggests that existing constraints can be an important motive for technology partnering (Drechsler and Natter, 2012; Garriga et al., 2013). On the other hand, constraints on resources may also render the firm less attractive as R\&D collaboration partner, and may reduce the general intensity of its innovative activities, including R\&D collaborative endeavors. We create a resource constraints variable from survey items related to the following topics: 1 ) bottlenecks in the innovation process caused by high costs or lack of financial resources 2) uncertainty about market conditions 3) organizational bottlenecks 4) shortage of qualified (R\&D) human resources 5) lack of information. Following Garriga et al. (2013) we coded these items as binary variables indicating the presence or absence of the constraint (Chronbach's $\alpha=0.76$ ) and then added them up.

The analysis includes a patent dummy, which takes the value one (else zero) if a firm used patents as a means to protect its inventions. The possession of patents may provide firms with reputational value as effective innovators. Prior studies also have suggested that the capability of firms to protect and appropriate the fruits of technology development (through patents) generally has a positive effect on innovation and R\&D collaboration (e.g. Hurmelinna-Laukkanen, 2011). In addition, the analysis controls for the patent productivity of the firm, defined as the ratio of the number of patent applications (during the past three years) to R\&D expenditures. This variable controls for firms ' broader propensity to enhance appropriation of their technological inventions through patents, as well as for differences in firms' technological performance after controlling for R\&D inputs.

\footnotetext{
${ }^{3}$ We also estimated models with 3 year lags for persistent prior R\&D collaboration. This reduced the sample of observations by a large margin. Results were qualitatively similar but with higher estimated standard errors. There was no indication that the effects of persistence were stronger when measuring this over a longer prior period.

4 Substituting the simple percentage of innovative sales in total sales as a performance measure leads to indiscriminate empirical results across collaboration types, with positive linear and negative square terms. We take this as indicating that this measure is less able to properly distinguish differences in relevant innovation performance across firms. Substituting an alternative measure that includes efficiency considerations - innovative sales over R\&D - does produce qualitative similar results with an inverted-U shaped relationship only discernible for competitor collaboration.

5 Taking a productivity measure also aligns with extant literature relating innovation and best practice specifically to productivity (e.g. Bloom et al. 2012).
} 
Our models also include the ratio of the firm's expenditure on applied and basic research (i.e. the ' $R$ ' part of R\&D) to the firm's expenditures on development (the ' $D$ ' part of $R \& D$ ). Prior research has emphasized different roles played by ' $R$ ' and ' $D$ ' in fostering innovation (e.g. Barge-Gil and Lopez, 2015). While basic and applied research is geared towards acquiring complex and tacit knowledge, development is more focused on applied and codified knowledge. R\&D collaboration with universities \& research institutes may for instance be more strongly associated with a higher ratio of ' $R$ ' to ' $D$ '.

Finally, the model includes a set of 18 industry dummies and a set of year dummies. All time-variant control variables are lagged by one year.

\section{Empirical model}

We estimate a model in which we explain the propensity of a firm to start R\&D collaboration with a new partner type depending on the patterns of prior R\&D collaboration and past innovative performance. In order to analyze the propensity of firms to form new $R \& D$ collaborations with each type of partner, we estimate four binary choice equations for R\&D collaboration with competitor, customer, supplier and universities \& research institutes. Since these decisions are taken simultaneously we estimate the equations jointly, using a multivariate limited dependent variable model (Roodman, 2011) allowing for correlated error terms across equations. Such correlations are likely if there are benefits in joint new R\&D collaboration engagement, or in case there are omitted variables in our empirical model of these choice processes. We estimate these models with robust standard errors clustered by firm. The general form of our model is as follows:

$$
y_{i, k}=\left\{\begin{array}{ll}
1 & \text { if } x_{i, k} \beta_{k}+\omega_{i, k}>0 \\
0 & \text { otherwise }
\end{array} \quad, \mathrm{k}=1, \ldots, 4 ; \quad \mathrm{i}=1, \ldots, \mathrm{N}\right.
$$

where $\mathrm{y}_{1}, \mathrm{y}_{2}, \mathrm{y}_{3}$ and $\mathrm{y}_{4}$ are the four binary dependent variables, i.e. new customer, supplier, competitor and institutional R\&D collaboration and $\left(\omega_{1} \omega_{2} \omega_{3} \omega_{4}\right) \sim N(0, \Sigma)$ where $\Sigma$ is the covariance matrix of the error terms.

Although our focus is on specific patterns of inter-temporal interrelationships between R\&D collaborative R\&D with different types of partners in order to test our hypotheses, our empirical model includes a full set of indicators of prior R\&D collaboration. This is because we cannot rule out that different types of interrelationships exist beyond the hypothesized relationships, such that limiting the analysis to a specific set of prior R\&D collaboration patterns may lead to omitted variable bias.

To address potential sample selection concerns due to our focus on innovation-active firms from an initial larger selection of firms, we implemented a two-stage approach, correcting for selection effects. We estimated a first-stage probit model that explains firms' propensity to be an innovator and subsequently include the Inverse Mill's ratio of this equation as an additional covariate in the R\&D collaboration models (e.g. Hass and Hansen, 2005). In the first stage model we include firm size, export orientation (as the pressure to innovate and renew products is likely to be greater for firms competing in international markets), and a dummy that equals one (else zero) if a firm is newly established. Recent research has shown that young firms are often more innovative compared to their established counterparts (Schneider and Veugelers, 2010). In addition, we include a dummy variable for firms that are part of a business group, as being a part of a larger business group can provide input to innovation-orientated activities of the focal firm. Finally, we include industry and time dummies. The first stage model was highly significant with all covariates having a significantly positive coefficient.

\section{Empirical results}

Table 2 contains summary statistics and the bivariate correlations between the variables used in the estimation. Supplier and institutional $R \& D$ collaboration are most prominent, while R\&D collaborations with competitors and customers are observed much less frequently. Persistent R\&D collaboration in general is more frequently observed than new or discontinued R\&D collaboration. In addition we can report that for 3407 firm-year observations, at least one R\&D collaboration agreement with customers, suppliers, competitors or research institutes and universities is reported. Firms on average have an R\&D intensity of close to four percent, and about 80 percent of the sample firms are exporters. The variance inflation factor (VIF) values (with a mean of 2.6 across all variables) do not indicate multi-collinearity concerns.

The empirical results of the multivariate limited dependent variables model explaining the formation of new $R \& D$ collaboration with suppliers, customers, competitors and universities \& research institutions are displayed in Table 3, in columns 1 through 4 . The bottom pane of the table reports the estimated correlations between the errors terms of the equations, which are all significant $(p<0.01)$, confirming that a multivariate model taking these correlations into account is to be preferred. The Inverse Mills ratio is negative and significant in three of the four equations, suggesting that selection effects are present, and indicating, as expected, that the inverse of the probability that firms are innovators is negatively related to firms' propensity to establish new $R \& D$ collaborations. The model has a proper fit, as indicated by the significant log- 
Table 2

Descriptive statistics and pairwise correlations.

\begin{tabular}{|c|c|c|c|c|c|c|c|c|c|c|c|c|c|c|}
\hline & Variables & Mean & SD & 1 & 2 & 3 & 4 & 5 & 6 & 7 & 8 & 9 & 10 & 11 \\
\hline 1 & New supplier collab (dv) & 0.02 & 0.15 & & & & & & & & & & & \\
\hline 2 & New customer collab (dv) & 0.01 & 0.08 & 0.27 & & & & & & & & & & \\
\hline 3 & New competitor collab (dv) & 0.01 & 0.08 & 0.17 & 0.25 & & & & & & & & & \\
\hline 4 & New university \& res. inst. (dv) & 0.03 & 0.16 & 0.40 & 0.19 & 0.22 & & & & & & & & \\
\hline 5 & Innovation performance & 0.27 & 1.82 & 0.04 & 0.04 & 0.03 & 0.03 & & & & & & & \\
\hline 6 & Innovation performance squared & 3.38 & 5.01 & 0.04 & 0.04 & 0.02 & 0.02 & 0.81 & & & & & & \\
\hline 7 & Recent supplier collab & 0.03 & 0.16 & & 0.05 & 0.05 & 0.08 & 0.05 & 0.03 & & & & & \\
\hline 8 & Recent customer collab & 0.01 & 0.08 & 0.05 & & 0.06 & 0.06 & 0.04 & 0.03 & 0.17 & & & & \\
\hline 9 & Recent competitor collab & 0.01 & 0.08 & 0.03 & 0.01 & & 0.05 & 0.03 & 0.02 & 0.10 & 0.12 & & & \\
\hline 10 & Recent institutional collab & 0.03 & 0.17 & 0.07 & 0.03 & 0.04 & & 0.04 & 0.02 & 0.30 & 0.12 & 0.16 & & \\
\hline 11 & Persistent supplier collab & 0.06 & 0.23 & & 0.10 & 0.06 & 0.06 & 0.08 & 0.06 & -0.04 & 0.10 & 0.05 & 0.06 & \\
\hline 12 & Persistent customer collab & 0.01 & 0.10 & 0.04 & & 0.07 & 0.05 & 0.05 & 0.03 & 0.01 & -0.01 & 0.03 & 0.04 & 0.30 \\
\hline 13 & Persistent competitor collab & 0.01 & 0.09 & 0.02 & 0.03 & & 0.02 & 0.05 & 0.03 & 0.01 & 0.01 & -0.01 & 0.01 & 0.21 \\
\hline 14 & Persistent institutional collab & 0.05 & 0.23 & 0.08 & 0.07 & 0.06 & & 0.09 & 0.07 & 0.05 & 0.06 & 0.05 & -0.04 & 0.46 \\
\hline 15 & Discontinued supplier collab & 0.03 & 0.16 & 0.14 & 0.03 & 0.03 & 0.06 & 0.02 & 0.02 & -0.03 & 0.01 & 0.02 & 0.01 & -0.04 \\
\hline 16 & Discontinued customer collab & 0.01 & 0.08 & 0.05 & 0.13 & 0.05 & 0.03 & 0.02 & 0.02 & 0.01 & -0.01 & 0.01 & 0.01 & 0.08 \\
\hline 17 & Discontinued competitor collab & 0.01 & 0.09 & 0.05 & 0.07 & 0.08 & 0.05 & 0.02 & 0.02 & 0.01 & 0.01 & -0.01 & 0.01 & 0.06 \\
\hline 18 & Discontinued institutional collab & 0.03 & 0.17 & 0.05 & 0.02 & 0.01 & 0.12 & 0.02 & 0.02 & 0.02 & 0.03 & 0.02 & -0.03 & 0.05 \\
\hline 19 & Firm size & 4.21 & 1.36 & 0.11 & 0.07 & 0.06 & 0.08 & 0.06 & 0.04 & 0.10 & 0.06 & 0.04 & 0.08 & 0.22 \\
\hline 20 & R\&D intensity, \% & 3.71 & 6.16 & 0.02 & 0.02 & 0.01 & 0.02 & 0.08 & 0.02 & 0.02 & 0.02 & 0.01 & 0.03 & 0.02 \\
\hline 21 & Export intensity, \% & 10.56 & 18.31 & 0.04 & 0.05 & 0.05 & 0.04 & 0.05 & 0.05 & 0.05 & 0.05 & 0.05 & 0.03 & 0.07 \\
\hline 22 & Constraints on resources & 1.77 & 1.86 & -0.03 & -0.02 & -0.01 & -0.02 & -0.03 & -0.03 & -0.01 & -0.01 & 0.00 & 0.00 & -0.05 \\
\hline 23 & Patents/R\&D & 0.04 & 0.46 & 0.00 & 0.00 & 0.00 & 0.00 & 0.03 & 0.01 & 0.00 & 0.00 & 0.00 & -0.01 & -0.01 \\
\hline 24 & Patent dummy & 0.16 & 0.37 & 0.05 & 0.07 & 0.04 & 0.05 & 0.17 & 0.10 & 0.07 & 0.06 & 0.01 & 0.06 & 0.11 \\
\hline \multirow[t]{2}{*}{25} & 'R' to 'D' expenditures ratio & 0.33 & 0.40 & 0.03 & 0.02 & 0.02 & 0.03 & 0.07 & 0.05 & 0.03 & 0.02 & 0.02 & 0.03 & 0.06 \\
\hline & Variables & 12 & 13 & 14 & 15 & 16 & 17 & 18 & 19 & 20 & 21 & 22 & 23 & 24 \\
\hline 13 & Persistent competitor collab & 0.13 & & & & & & & & & & & & \\
\hline 14 & Persistent institutional collab & 0.19 & 0.16 & & & & & & & & & & & \\
\hline 15 & Discontinued supplier collab & 0.00 & 0.00 & 0.04 & & & & & & & & & & \\
\hline 16 & Discontinued customer collab & -0.01 & 0.03 & 0.06 & 0.24 & & & & & & & & & \\
\hline 17 & Discontinued competitor collab & 0.06 & -0.01 & 0.07 & 0.17 & 0.25 & & & & & & & & \\
\hline 18 & Discontinued institutional collab & 0.03 & 0.01 & -0.04 & 0.32 & 0.16 & 0.18 & & & & & & & \\
\hline 19 & Firm size & 0.10 & 0.06 & 0.19 & 0.09 & 0.07 & 0.05 & 0.06 & & & & & & \\
\hline 20 & R\&D intensity, \% & 0.03 & 0.01 & 0.05 & 0.01 & 0.01 & 0.02 & 0.01 & -0.25 & & & & & \\
\hline 21 & Export intensity, \% & 0.06 & 0.06 & 0.05 & 0.04 & 0.05 & 0.05 & 0.03 & 0.09 & 0.04 & & & & \\
\hline 22 & Constraints on resources & -0.03 & -0.02 & -0.02 & -0.02 & -0.01 & -0.01 & -0.01 & -0.22 & 0.10 & -0.03 & & & \\
\hline 23 & Patents/R\&D & -0.01 & 0.00 & -0.01 & -0.01 & 0.00 & 0.00 & 0.00 & -0.03 & -0.02 & 0.00 & 0.00 & & \\
\hline 24 & Patent dummy & 0.04 & 0.04 & 0.10 & 0.03 & 0.05 & 0.03 & 0.04 & 0.11 & 0.11 & 0.09 & 0.00 & 0.18 & \\
\hline 25 & 'R' to 'D' expenditures ratio & 0.05 & 0.03 & 0.04 & 0.02 & 0.01 & 0.02 & 0.02 & 0.05 & 0.10 & 0.08 & 0.00 & -0.01 & 0.08 \\
\hline
\end{tabular}

Notes: $d v=$ dependent variable. Collab refers to $R \& D$ collaboration. Persistent $R \& D$ collaboration is ongoing involvement in $R \& D$ collaboration of the same partner type. There is no correlation between new R\&D collaboration with a partner type and prior (persistent or recent) R\&D collaboration with the same partner type as this combination cannot occur. Correlations report on a sample of 26,608 observations.

likelihood ratio test, and has satisfactory predictive power as indicated by the area under the ROC curve statistic (Hosmer and Lemeshow, 2000; StataCorp, 2015): a statistic of approximately 0.8 indicates acceptable levels of discrimination between the absence or presence of new R\&D collaborations. ${ }^{6}$ Further analysis also showed that the inclusion of the focal variables leads to a significant and substantial improvement in model fit for each dependent variable. ${ }^{7}$

In support of Hypothesis 1 a, the empirical results show (column 1 of Table 3 ) that both recent $(\mathrm{p}<0.01)$ and persistent ( $p<0.1$ ) customer R\&D collaboration exert a positive influence on the probability that a firm starts R\&D collaboration with suppliers. Similarly, in support of Hypothesis 1b, results show (see column 2 of Table 3 ) that both recent (p < 0.01 ) and persistent ( $p<0.01$ ) supplier R\&D collaboration exert a positive influence on the probability that a firm starts R\&D collaboration with customers. Discontinued customer (supplier) R\&D collaboration, in contrast, is not significant in the supplier (customer) equation - consistent with Hypotheses $1 \mathrm{a}$ and $1 \mathrm{~b}$.

Hypothesis 2 predicts that firms that discontinued R\&D collaboration with competitors in t- 1 have a higher propensity to start R\&D collaboration with suppliers, customers and universities \& research institutes. The coefficient on discontinued competitor $\mathrm{R} \& \mathrm{D}$ collaboration is positive and (weakly) significant in the supplier $(\mathrm{p}<0.1$ ), customer ( $\mathrm{p}<0.1)$ and universities $\&$ research institutes $(\mathrm{p}<0.1)$ equations. In contrast, the coefficients on recent and persistent competitor R\&D collaboration are all insignificant. These results provide qualified support for Hypothesis 2.

\footnotetext{
${ }^{6}$ The ROC is an aggregate indicator of predictive power proposed by Hosmer and Lemeshow (2000) that measures the rate (0-1) of correct predictions of occurrence and non-occurrence of the focal phenomenon (new R\&D collaboration in our case). We also confirmed a substantial and significant improvement in model fit compared to a model including only the control variables.

${ }^{7}$ Estimating separate probit models, we confirmed that the fit of the individual models and the pseudo R2 improved considerably and significantly (LR tests).
} 
Table 3

Antecedents of the establishment of R\&D collaboration with new partner types: results of a multivariate probit model.

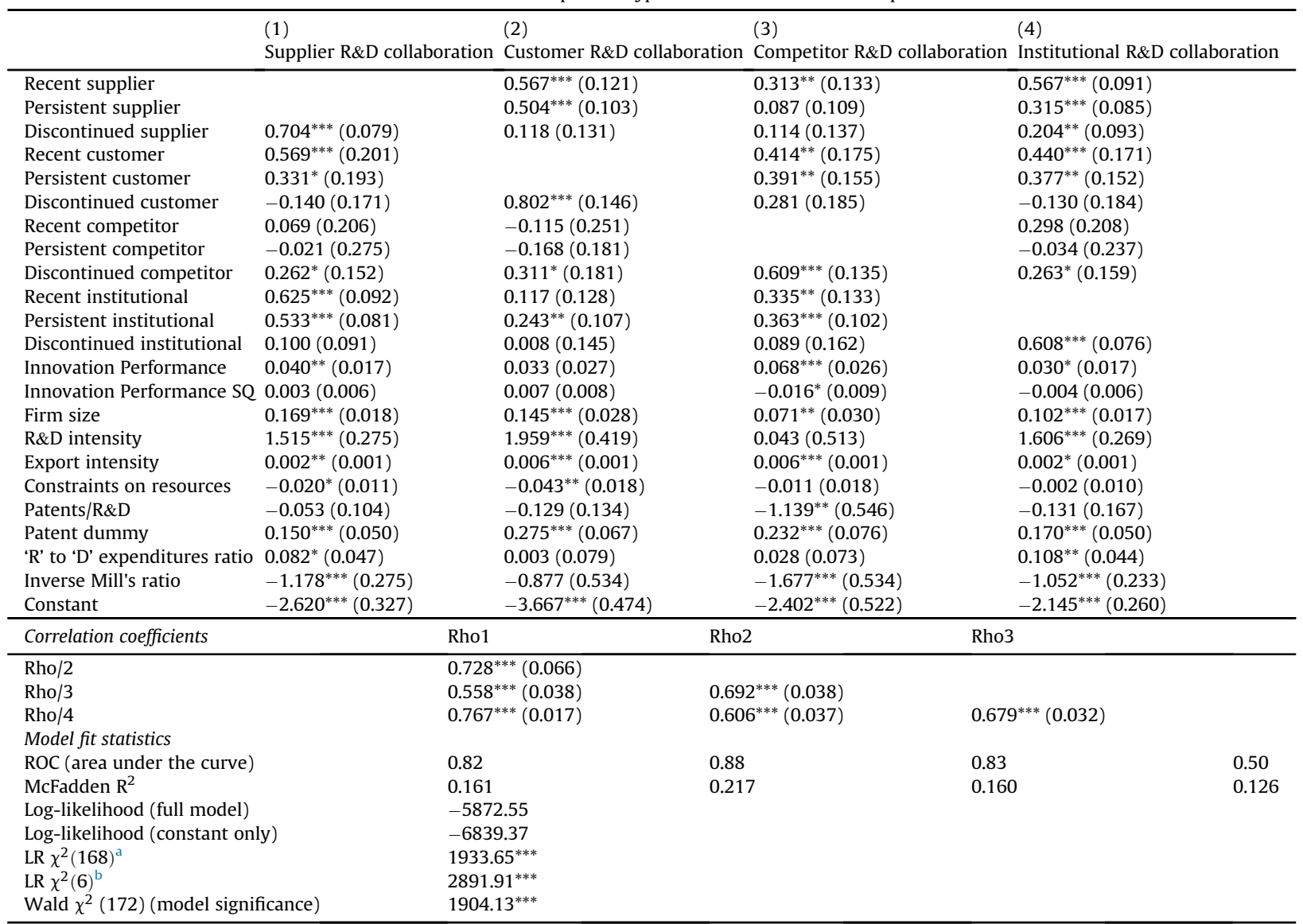

Notes: 18 industry and 5-year dummies are included. Robust (clustered) standard errors in parentheses. Mc Fadden statistics are based on re-estimation of the model as separate probit models. Persistent R\&D collaboration is ongoing involvement in R\&D collaboration of the same partner type.

* Significant at $10 \%$; ** Significant at $5 \%$; *** Significant at $1 \%$.

a Likelihood-ratio test between the constant-only model and the full model.

b Likelihood-ratio test of all correlation coefficients rho $=0$.

In support of Hypothesis 3, the results suggest that prior persistent R\&D collaboration with universities \& research institutes is a significant antecedent of the start of R\&D collaborations across all other partner types in line with Hypothesis 3 , with persistent institutional R\&D collaboration significant at the 1 or 5 percent level in the supplier, customer and competitor equations. At the same time, recent R\&D collaboration with universities \& research institutes is positively associated with the start of supplier and competitor R\&D collaboration, but not with customer R\&D collaboration.

Hypothesis 4 predicts that firms that discontinued their cooperative R\&D relationships with a particular type of partner previously (in year t-1), have a higher probability of re-establishing R\&D collaboration with that partner type in the future (year $\mathrm{t}$ ). The results provide strong support for this hypothesis, as prior discontinued R\&D collaboration has a positive and significant $(p<0.01$ ) influence on the (re)start of $R \& D$ collaboration for every type of partner (suppliers, customers, competitors and research institutions). This is a salient finding because such a positive influence of discontinued R\&D collaboration is not observed across partner types, apart from the hypothesized effects of prior discontinued competitor $\mathrm{R} \& \mathrm{D}$ collaboration.

Table 3 shows that past innovative performance has a positive association with the formation of R\&D collaboration with suppliers and universities \& research institutes. In these cases, the relationship is linear (the quadratic term is insignificant) as hypothesized. For customer $R \& D$ collaboration, innovative performance does not appear to be a significant factor in increasing the propensity for R\&D collaboration. However, if in further tests (not shown due to space limitations) the quadratic term is omitted, the results reveal a strongly significant linear relationship. The only R\&D collaboration type for which negative effects of innovative performance may occur is competitor R\&D collaboration. With a significant positive linear term and a significant negative squared term, the estimates confirm an inverted-U shaped relationship. The estimated coefficients suggest that innovative performance has a positive marginal effect on propensity to establish competitor R\&D collaborations up to roughly the top decile in the sample distribution, after which performance reduces the probability to start R\&D collaboration with competitors. Overall, these findings provide broad support for Hypothesis 5. 
The implied size of the effects of different patterns of prior R\&D collaboration on the propensity to establish R\&D collaborations with new partner types are substantial. The coefficients suggest that existing engagement in R\&D collaboration, depending on the relationship between types, can easily double the probability that a firm establishes a new type of R\&D collaboration. For instance, existing customer R\&D collaboration more than doubles the probability that a firm starts R\&D collaboration with suppliers (120 percent), and existing supplier R\&D collaboration increases the probability of new engagement in customer R\&D collaboration by 90 percent. The strongest effects are estimated for the re-establishment of existing partner type R\&D collaboration (the effect of prior discontinued R\&D collaboration), with effect sizes between 115 and 175 percent (the latter for discontinued supplier R\&D collaboration).

The results reveal a number of additional relationships between prior R\&D collaboration and the likelihood of establishing $R \& D$ collaborations with new partner types. While existing $R \& D$ collaboration with universities \& research institutes is a precursor of R\&D collaboration with other partner types, prior (recent or persistent) supplier and customer R\&D collaboration in turn increases the probability that firms start institutional R\&D collaboration. This suggests a broader complementarity between these collaborative ties in $R \& D$. In general, supplier and customer $R \& D$ collaboration appear to have broader relevance as a precursor of the start of R\&D collaboration with other partner types.

The results for the control variables show that larger firms, more R\&D intensive firms, exporting firms and firms applying for patents are more likely to establish R\&D collaborations with new partner types. One exception is an insignificant coefficient on $R \& D$ intensity in the competitor $R \& D$ collaboration equation. A possible explanation is that firms with relatively abundant $R \& D$ resources and funds for the marketing and introduction of innovations have less need to forge new R\&D collaborative ties, while such ties with competitors in addition face the risk of dissipation of knowledge to direct rivals in the product market (e.g. Belderbos et al., 2004a,b; Ritala et al., 2015). The same logic may apply to a negative coefficient on patent productivity: successful firms with proprietary knowledge to protect are relatively less likely to start R\&D collaboration with competitors. Consistent with expectations, higher ratios of ' $R$ ' to ' $D$ ' expenditures are associated with the start of $R \& D$ collaboration with universities \& research institutes. This also holds for supplier R\&D collaboration but not for competitor and customer R\&D collaboration. Finally, firms experiencing constraints on resources are less likely to start R\&D collaborations with suppliers or customers, perhaps because these constraints also hamper new commitments to R\&D in collaborative projects.

\section{Conclusion and discussion}

\section{Key findings}

Whereas operating R\&D collaboration portfolios is seen as carrying significant outcome effects for firms (e.g., Jiang et al., 2010; Hashai et al., 2015), prior studies have not paid due attention to the question how firms' R\&D collaboration portfolios are adapted and what the main drivers of such adaptations are. Our study addresses this issue and takes a dynamic and integrative approach to analyze the adaptation of firms' R\&D collaboration portfolios consisting of different partner types (customers, suppliers, competitors, and research institutes and universities).

We find support for a hypothesized strong interrelationship between new customer (supplier) R\&D collaborative R\&D ties and prior supplier (customer) R\&D collaboration, which we attribute to the advantages of close intertemporal alignment of $R \& D$ collaboration with value chain partners. Close alignment allows knowledge exchange and coordination to take place in 'real time', reduces the risks of inconsistencies across value chain steps, improves efficiency by elimination of duplicative efforts, and decreases chances of misunderstanding. In contrast, prior horizontal R\&D collaboration with competitors only has a positive effect on the formation of R\&D collaboration with a new partner type if the R\&D collaboration with competitors was first discontinued. This confirms our Hypothesis that a sufficient lag between competitor R\&D collaboration and R\&D collaboration with other partner types mitigates governance risks related to undesirable knowledge spillovers and freeridership across collaborations with the different types if partners. Hence, in case of existing competitor R\&D collaboration, there is a delayed rather than a close intertemporal alignment of $R \& D$ collaboration with other partner types.

We also observe that prior $R \& D$ collaboration with public research institutions and universities is an important antecedent of the start of R\&D collaboration with other partner types, in particular when such R\&D collaboration with institutions is persistent - although (weaker) positive relationships are also found for more recently established institutional R\&D collaboration. Institutional $R \& D$ collaboration can give incentives and opportunities to augment the R\&D collaboration portfolio with other partner types because the novel, generic knowledge and new technologies generated can be exploited in more applied R\&D collaborative projects with other partner types. Institutional R\&D collaboration offers firms opportunities to better assess which ( $R \& D$ collaborative) trajectories in applied research will be most promising, and to benefit from positive reputational effects of involvement in collaborative university research.

Empirical results confirmed a stylized pattern of a renewed R\&D collaboration: discontinued R\&D collaboration with a partner type increases the probability of a subsequent restarting of $R \& D$ collaboration with that type of partner. If a given $R \& D$ collaboration fails because the existing collaborating firm or institution is no longer the best match or willing to continue, resource constraints and innovation needs will favor re-initiation of R\&D collaboration with the same partner type addressing the same strategic need.

Finally, we identify a key role of past innovative performance in adaptation of R\&D collaboration portfolios by adding R\&D collaboration with new partner types. Firms with better past innovative performance (in terms of their productivity in 
bringing new products to the market) are generally more likely to start R\&D collaborations with new partner types subsequently, which will be due to the fact that they are more attractive as R\&D collaboration partners. However, this is not the case for 'horizontal' R\&D collaboration with competitors. Here the risk of dissipation of know-how to rivals - with potential detrimental effects on a firm's market position - discourages R\&D collaboration by firms with the strongest innovative performance.

\section{Contributions and implications for theory}

A first insight that our study contributes to the literature on R\&D and R\&D collaboration (e.g. Rothaermel and Deeds, 2004; Gilsing et al., 2008; Gittelman and Kogut, 2003; Srivastava and Gnyawali, 2011), is that the adaptation of R\&D collaboration portfolios follows distinctly different patterns depending on the type of partner. Here our study extends prior work considering adaptations of alliance portfolios with a focus on the distinction between exploration and exploitation alliances (Koza and Lewin, 1998; Rothaermel and Deeds, 2004). Our results on the role of institutional (university) collaboration as driver of the subsequent formation of collaborations with other partner types is broadly in line with earlier findings that the more explorative alliances create a subsequent need for exploitation alliances (Rothaermel and Deeds, 2004) - although our study suggests that this pattern is strongest for persistent institutional collaboration. At the same time, whereas prior studies suggest a uniform relationship running from exploration to exploitation alliances, our study contributes by showing that there also is considerable heterogeneity in alliance formation dynamics. Opening up the black box of different partner types reveals a dynamic pattern of start, dis-continuation and renewal of collaboration as well as considerable differences in these patterns across partner types. Whereas temporal alignment is critical for accomplishing complementarity across different partner types, how this is achieved differs profoundly between vertical and horizontal R\&D collaboration, with attendant consequences for the adaptation of the R\&D collaboration portfolio with new partner types. For vertical R\&D collaboration temporal alignment needs to be (very) close in time in order to reap coordination advantages, but for horizontal $\mathrm{R} \& \mathrm{D}$ collaboration there is delayed alignment to reduce the risk of knowledge dissipation to rivals.

A second new insight with relevance to the literature on $R \& D$ and $R \& D$ collaboration is that prior innovation performance also serves as an antecedent of the adaptation of the R\&D collaboration portfolio with new partner types, yet that its influence also differs between partner types: horizontal R\&D collaboration with competitors forms the exception. Our findings here shed more light on the 'opportunities and inducement' framework of Ahuja (2000a): while firms may have clear opportunities to initiate $R \& D$ collaborations with a new partner type and have sufficient absorptive capacity to potentially benefit from R\&D collaboration (Spithoven et al., 2010), they may still have insufficient inducements for horizontal R\&D collaboration with competitors if they fear that rival firms may benefit asymmetrically from the agreement. Hence, we highlight that there is a fundamental difference between horizontal $R \& D$ collaboration with competitors vis-à-vis vertical $R \& D$ collaboration with suppliers and customers and R\&D collaboration with institutions - both in terms of temporal alignment and in the recursive effect of prior innovation performance. This insight contributes to a more in-depth understanding of the heterogeneous drivers of a firm's R\&D collaboration portfolio adaptations.

Third, whereas in previous work on alliance networks the role of relational, structural and positional embeddedness (Gulati and Garguilo, 1999; Stuart et al., 1999) has been emphasized in the formation of collaborative R\&D ties, or the role of partners' resources (e.g. Ahuja et al., 2009), our study suggests that it is critical to also consider heterogeneity across partner types. The majority of network embeddedness studies has abstracted from a partner's role along the value chain, or has considered either horizontal (e.g. Ahuja, 2000b) or vertical types (e.g. Gulati and Sytch, 2007). Our study shows that there is strong heterogeneity in how different partner types influence the formation of R\&D collaboration with new partner types. Apart from the role of embeddedness and partners' resources ('nodal attributes' in network parlance) in explaining the formation of new R\&D collaborations, a firm's recently established, persistent and prior discontinued R\&D collaborations with the same or different partner types are of significant influence. We suggest that future research takes into account the specific roles and functions of R\&D collaborations with different partner types.

Another implication of our study relates to the recursive process between the formation of R\&D collaborations and performance outcomes. The dominant focus in different bodies of literature until now has been on either antecedents or performance consequences of $R \& D$ collaboration - but examined these in isolation. Moreover, these literature have investigated this in a rather compartmentalized manner, either from a resource dependency based perspective emphasizing the sharing of resources and strategic interdependence (e.g. Gulati and Gargiulo, 1999; Hagedoorn, 2002; Powell et al., 1996), from a network structural perspective emphasizing the network position of partners (e.g. Ahuja, 2000b; Rowley et al., 2000), or from an industrial organization perspective emphasizing the internalization of knowledge spillovers (e.g. Belderbos et al., 2004b). These different lines of research share a common assumption of a linear process of antecedents leading to the formation of collaborative R\&D ties, which subsequently leads to performance. This approach is also often taken in prior studies analyzing the evolution of R\&D collaboration portfolio emphasizing how exogenous changes in the environment affect portfolio change (e.g. Koza and Lewin, 1998; Koka et al., 2006; Lavie and Singh, 2011).

Our study instead has adopted a strategy perspective to show how the decision to start R\&D collaboration with a new partner type and adapt the R\&D collaboration portfolio is a dynamic function of a firm's recently established, persistent or prior discontinued R\&D collaborations. This is reflective of a more agency-oriented understanding that demonstrates how, once R\&D collaborations with a partner type are formed, continued, or discontinued, a sequence of further decisions unrolls on the formation of new R\&D collaboration with different partner types. The pervasive role of these inter-temporal dynamics, 
in which $R \& D$ collaborations with other partner types are added to firms' R\&D collaboration portfolios, is indicative of several key processes in inter-firm R\&D collaboration that have not been captured by the common, linear approach to the analysis of antecedents and performance consequences of R\&D collaboration dominating the literature thus far. Our study in this regard ties into an emergent stream in the literature that is concerned with opening the 'black box' of the R\&D collaboration process, studying the intricacies and micro-mechanisms of how firms can realize the potential value of R\&D collaboration (see e.g. Kauppila, 2015; Hipkin and Naudé, 2006; Newell et al., 2008; Cassiman et al., 2009). We suggest that future research on R\&D and R\&D collaboration should pay close attention to the dynamics of the growth in firms' heterogeneous R\&D collaboration portfolios, with the performance consequences of alignment and temporal patterns of R\&D collaboration forming a promising avenue for further inquiry.

\section{Managerial implications}

An important implication following from our study is that collaboration for innovation cannot be captured by a universal 'best practice', as is (implicitly) assumed or sometimes even explicitly argued in the literature on e.g. open innovation (e.g. Chesbrough et al., 2014) or the more popular business press (e.g. Skarzynski and Gibson, 2008; Govindarajan, 2016). As several success stories on R\&D collaboration for innovation have demonstrated (e.g. Procter and Gamble's connect and develop program, IBM's emerging business areas, or Lego's radical innovation's strategy, to name a few), and as demonstrated by different studies (Ahuja, 2000b; Rothaermel and Deeds, 2004; Gilsing et al., 2008), R\&D collaboration for innovation holds the promise of delivering value and enhancing performance. Our study does not criticize these claims, but suggests that in order to maintain the ability of capturing value from $R \& D$ collaboration, firms may have to adapt the R\&D collaboration portfolio on an ongoing basis (e.g. Koka et al., 2006; Ahuja et al., 2012). To accomplish this, and in order to benefit from its performance enhancing effects, it is important to be aware that a fundamental difference exists in the dynamics between $R \& D$ collaboration with competitors (horizontal) on the one hand, and R\&D collaboration with suppliers and customers (vertical) and universities \& research institutes (institutional) on the other hand. Hence, building up (R\&D) alliance capabilities (Heimeriks et al., 2009) requires recognition of the distinct differences in collaboration processes depending on the partner type.

A recently emerging phenomenon in business practice is an increasingly important role of (alliance) network managers, entrusted with steering and coordinating network activities, in particular complex innovation networks such as, among others, R\&D collaboration portfolios involving different partner types (Landsperger et al., 2012; Heidenreich et al., 2016). The implication for firms and their network managers is that when setting up R\&D collaborations with a new partner type, taking into account the nature of existing R\&D collaborations is critically important. When collaborating with suppliers, customers and/or research institutions, temporal alignment is relatively easy and safe to accomplish, enhancing a firm's ability to adapt rapidly its portfolio of $R \& D$ collaborations if needed. This differs for $R \& D$ collaboration with competitors where the need for delayed alignment will reduce the speed of adaptability of a firm R\&D collaboration portfolio. Hence, before setting up R\&D collaboration with competitors, it is important to be aware that this comes not only at a price of elevated risks of spillovers and opportunism, but will also lower the speed of adaptation of the R\&D collaboration portfolio if one wants to address these risks. Given the ever-increasing velocity in today's dynamic business environments, which puts a premium on adaptability (Stieglietz et al., 2016), adaptation of R\&D collaboration portfolios will form an increasingly critical issue to consider.

\section{Limitations}

We note a number of limitations of our research. First, our analysis relied on information concerning engagement in R\&D collaboration with different partner types, but could not identify individual partners of the focal firms. Our theory and analysis therefore took a strategic perspective on the rationale for engagement in $R \& D$ collaboration with different partner types, rather than focusing on the start, longevity, and termination of individual R\&D collaborations.

Second, a number of aspects of the R\&D collaboration patterns may be specific to the data on Spanish firms that we analyzed. In Spain, the majority of the national R\&D effort is carried out by the public sector. Firms are therefore likely to have relatively strong incentives to cooperate with research institutions, and such $R \& D$ collaboration is often supported by public policies. This may explain why institutional R\&D collaboration is rather well represented in our sample. We suggest that future work examines the patterns of dynamic interrelation and performance drawing on innovation surveys in other countries to investigate the generalizability of our findings. Our analysis suggests that it will be important to access yearly data on R\&D collaboration in order to unveil dynamic patterns of interrelation.

Third, we examined new R\&D collaboration as a function of past innovative performance - in an implicit recursive model. While this brought out salient and dynamic heterogeneity in collaborative R\&D activities with different partners, we cannot infer causality. In general, while the lag structure helps to alleviate concerns about reverse causality, our analysis cannot rule out endogeneity stemming from unobserved heterogeneity and potential influences of long-term R\&D collaborative ties on past performance. We therefore interpret our results as partial correlations (associations) rather than causal relationships. A challenge for future work is to integrate performance analysis and the analysis of the drivers of R\&D collaboration within a single framework and system of equations. 
We hope that future research on $R \& D$ and $R \& D$ collaboration can pay close attention to the dynamics of the growth in firms' heterogeneous R\&D collaboration portfolios, with the performance consequences of alignment and temporal patterns forming a promising avenue for further inquiry.

\section{References}

Ahuja, G., 2000a. The duality of R\&D collaboration: inducements and opportunities in the formation of interfirm linkages. Strateg. Manag. J. 21 (3), $317-343$.

Ahuja, G., 2000b. R\&D collaboration networks, structural holes, and innovation: a longitudinal study. Adm. Sci. Q. 45, 425-455.

Ahuja, G., Soda, G., Zeheer, A., 2012. The genesis and dynamics of organizational network. Organ. Sci. 23 (2), 434-448.

Ahuja, G., Polidoro, F., Mitchell, W., 2009. Structural homophily or social asymmetry? The formation of alliances by poorly embedded firms. Strategic Management Journal 30, 941-958.

Arranz, N., Arroyabe, J., 2008. The choice of partners in R\&D collaboration: an empirical analysis of Spanish firms. Technovation 28, 88-100.

Baba, Y., Shichijo, N., Sedita, S., 2009. How do R\&D collaborations with universities affect firms' innovative performance? The role of "Pasteur scientists" in the advanced materials field. Res. Policy 38 (5), 756-764.

Barge-Gil, A., Lopez, A., 2015. R versus D: estimating the differentiated effect of research and development on innovation results. Ind. Corp. Change 24 (1), 93-129.

Barney, J., 1991. Firm resources and sustained competitive advantage. J. Manag. 17 (1), 99-120.

Bayona, C., Garcia-Marco, T., Huerta, E., 2001. Firms' motivations for cooperative R\&D: an empirical analysis of Spanish firms. Res. Policy 30 (8), $1289-1307$.

Becker, W., Dietz, J., 2004. R\&D cooperation and innovation activities of firms-evidence for the German manufacturing industry. Res. Policy 33 (2), 209-223.

Belderbos, R., Gilsing, V., Suzuki, S., 2016. Direct and mediated ties to universities: 'scientific' absorptive capacity and innovation performance of pharmaceutical firms. Strateg. Organ. 14 (1), 32-52.

Belderbos, R., Carree, M., Lokshin, B., Fernández Sastre, F., 2015. Inter-temporal patterns of R\&D collaboration and innovative performance. J. Technol. Transf. $40(1), 123-137$.

Belderbos, R., Gilsing, V., Lokshin, B., 2012. Persistence of, and interrelation between horizontal and vertical technology alliances. J. Manag. 38 (6), $1788-1811$.

Belderbos, R., Carree, M., Lokshin, B., 2004a. Cooperative R\&D and firm performance. Res. Policy 33 (10), 1477-1492.

Belderbos, R., Carree, M., Lokshin, B., Veugelers, R., Diederen, D., 2004b. Heterogeneity in R\&D cooperation strategies. Int. J. Ind. Organ. 22 (8-9), $1237-1263$.

Bercowitz, J.E.L., Feldman, M.P., 2007. Fishing upstream: firm innovation strategy and university research alliances. Res. Policy 36, 930-948.

Bleeke, J., Ernst, D., 1991. The way to win in cross-border alliances. Harv. Bus. Rev. 69 (6), 127-135.

Blomqvist, K., Hurmelinna, P., Seppanen, R., 2005. Playing the R\&D collaboration game right - balancing trust and contracting. Technovation 25, $497-504$.

Bloom, N., Genakos, C., Sadun, R., Van Reenen, J., 2012. Management practices across firms and countries. Acad. Mangement Perspect. 26 (1), $12-33$.

Brown, S., Eisenhardt, K., 1995. Product development: past research, present findings, and future directions. Acad. Manag. Rev. 20 (2), $343-378$.

Burt, R.S., 2004. Structural holes and good ideas. Am. J. Sociol. 110 (2), 349-399.

Cassiman, B., Chiara Di Guardo, M., Valentini, G., 2009. Organizing R\&D projects to profit from innovation: insights from co-opetition. Long. Range Plan. 42, 216-233.

Chesbrough, H., Vanhaverbeke, W., West, J., 2014. New Frontiers in Open Innovation. Oxford University Press, Oxford (UK).

Childerhouse, P., Aitken, J., Towill, D., 2002. Analysis and design of focused demand chains. J. Oper. Manag. 20 (6), 675-689.

Choi, T., Hartley, J., 1996. An exploration of supplier selection practices across the supply chain. J. Oper. Manag. 14 (4), $333-343$.

Cockburn, I., Henderson, R., 1998. Absorptive capacity, coauthoring behavior, and the organization of research in drug discovery. J. Ind. Econ. 46 (2), 157-182.

Cohen, W.M., Nelson, R., Walsh, J., 2002. Links and impacts: the influence of public research on industrial R\&D. Manag. Sci. 48 (1), 1-23.

Colombo, M.G., Grilli, L., Piva, E., 2006. In search of complementary assets: the determinants of alliance formation of high-tech start-ups. Res. Policy 35 , $1166-1199$.

Christensen, C.M., Bower, J.L., 1996. Customer power, strategic investment and the failure of leading firms. Strateg. Manag. J. 17, $197-218$.

Díez-Vial, I., 2007. Explaining vertical integration strategies: market power, transactional attributes and capabilities. J. Manag. Stud. 44 (6), 1017-1040.

Drechsler, W., Natter, M., 2012. Understanding a firm's openness decisions in innovation. J. Bus. Res. 65, 438-445.

Duysters, G., Lokshin, B., 2011. Determinants of alliance portfolio complexity and its effect on innovative performance of companies. J. Prod. Innovat. Manag. 28 (4), 570-585.

Faems, D., van Looy, B., Debackere, K., 2005. Interorganizational R\&D collaboration and innovation: toward a portfolio approach. J. Prod. Innovat. Manag. 22 (3), 238-250.

Fey, C., Birkinshaw, J., 2005. External sources of knowledge, governance mode, and R\&D performance. J. Manag. 31 (4), $597-621$.

Fisher, M., 1997. What is the right supply chain for your product? Harv. Bus. Rev. 75, 105-116.

Fleming, L., Sorenson, O., 2004. Science as a map in technological search. Strateg. Manag. J. 25 (8-9), 909-928.

Freel, M.S., 2003. Sectoral patterns of small firm innovation, networking and proximity. Res. Policy 32 (5), 751-770.

Frohlich, M., Westbrook, R., 2001. Arcs of integration: an international study of supply chain strategies. J. Oper. Manag. 19 (2), $185-200$.

Garriga, H., von Krogh, G., Spaeth, S., 2013. How constraints and knowledge impact open innovation. Strateg. Manag. J. 34 (9), $1134-1144$.

Gilsing, V.A., Nooteboom, B., 2006. Exploration and exploitation in biotechnology. Res. Policy 35 (1), 1-23.

Gilsing, V., Nooteboom, B., Vanhaverbeke, Duysters, G., Oord van den, A., 2008. Network embeddedness and the exploration of novel technologies: technological distance, betweenness centrality and density. Res. Policy 37 (12), 1717-1731.

Gittelman, M., Kogut, B., 2003. Does good science lead to valuable Knowledge? Biotechnology firms and the evolutionary logic of citation patterns. Manag. Sci. 49 (4), 366-382.

Govindajaran, V., 2016. The Three Box Solution, a Strategy for Leading Innovation. Harvard Business Review Press, Cambridge (MA).

Gregorio, D., Shane, S., 2003. Why do some universities generate more start-ups than others? Res. Policy 32 (2), 209-227.

Gulati, R., 1995. Does familiarity breed Trust? The implications of repeated ties for contractual choice in alliances. Acad. Manag. J. 38 (1), 85-112.

Gulati, R., Garguilo, M., 1999. Where do interorganizational networks come from? Am. J. Sociol. 104 (5), 1439-1493.

Gulati, R., Sytch, M., 2007. Dependence asymmetry and joint dependence in interorganizational relationships: effects of embeddedness on a manufacturer's performance in procurement relationships. Adm. Sci. Q. 52 (1), 32-69.

Hagedoorn, J., Lokshin, B., Zobel, A.-K., 2017. Partner type diversity in alliance portfolios: multiple dimensions, boundary conditions and firm innovation performance. J. Manag. Stud. Accepted.

Hagedoorn, J., 1993. Understanding the rationale of strategic technology partnering: interorganizational modes of cooperation and sectoral differences. Strateg. Manag. J. 14, 371-385.

Hagedoorn, J., 2002. Inter-firm R\&D partnerships: an overview of major trends and patterns since 1960. Res. Policy 31, 477-492.

Harrigan, K.R., 1988. Strategic alliances and partner asymmetries. In: Contractor, F., Lorange, P. (Eds.), Cooperative Strategies in International Business. Lexington Books, pp. 205-226.

Hashai, N., Kafouros, M., Buckley, P., 2015. The performance implications of speed, regularity, and duration in alliance portfolio expansion. J. Manag. https:// doi.org/10.1177/0149206315592030. Accepted. 
Haas, M., Hansen, M., 2005. When using knowledge can hurt performance: the value of organizational capabilities in a management consulting company. Strateg. Manag. J. 26, 1-24.

Heidenreich, S., Landsperger, J., Spieth, P., 2016. Are innovation networks in need of a conductor? Examining the contribution of network managers in low and high complexity settings. Long Range Plan. 49 (1), 55-71.

Heimeriks, K., Klijn, E., Reuer, E., 2009. Building capabilities for alliance portfolios. Long Range Plan. 42 (1), $96-114$.

Hipkin, I., Naudé, P., 2006. Developing effective alliance partnerships, lessons from a case study. Long Range Plan. 39 (39), $51-69$.

Hoffman, W., 2007. Strategies for managing a portfolio of alliances. Strateg. Manag. J. 28 (8), $827-856$.

Hosmer, D., Lemeshow, S., 2000. Applied Logistic Regression, second ed. Wiley, New York.

Hurmelinna-Laukkanen, P., Olander, H., 2014. Coping with rivals' absorptive capacity in innovation activities. Technovation 34, 3-11.

Hurmelinna-Laukkanen, P., 2011. Enabling collaborative innovation-knowledge protection for knowledge sharing. European Journal of Innovation Management 14 (3), 303-321.

Jacob, J., Belderbos, R., Gilsing, V., 2013. Technological alliances in emerging economies: persistence and interrelation in European firms' alliance formation. R\&D Manag. 43 (5), 447-460.

Jiang, R., Tao, Q., Santoro, M., 2010. Alliance portfolio diversity and firm performance. Strateg. Manag. J. 31 (10), $1136-1144$.

Kauppila, O., 2015. Alliance management capability and firm performance: using resource-based theory to look inside the process black box. Long. Range Plan. 48, 151-167.

Khanna, T., Gulati, R., Nohria, N., 1998. The dynamics of learning alliances: competition, cooperation, and relative scope. Strateg. Manag. J. 19 (3), $193-210$.

Killing, J., 1988. Understanding alliances: the role of tasks and organizational complexity. In: Contractor, F., Lorange, P. (Eds.), Cooperative Strategies in International Business. Lexington Books, pp. 55-68.

Kogut, B., 1989. The stability of joint ventures: reciprocity and competitive rivalry. J. Ind. Econ. 38 (2), $183-198$.

Koka, B., Madhavan, R., Prescott, J., 2006. The evolution of interfirm networks: environmental effects on patterns of network change. Acad. Manag. Rev. 31 (3), 712-731.

Koza, M.P., Lewin, A.Y., 1998. The co-evolution of strategic alliances. Organ. Sci. 9, 255-264.

Lahiri, N., Narayanan, S., 2013. Vertical integration, innovation, and alliance portfolio size: implications for firm performance. Strateg. Manag. J. 34 (9), $1042-1064$.

Landsperger, J., Spieth, P., Heidenreich, S., 2012. How network managers contribute to innovation network performance. Int. J. Innovat. Manag. 16 (6), 1240009.

Lavie, D., Kang, J., Rosenkopf, L., 2011. Balance within and across domains: the performance implications of exploration and exploitation in alliances. Organ. Sci. 22 (6), 1517-1538.

Lavie, D., Singh, H., 2011. The evolution of alliance portfolios: the case of Unisys. Ind. Corp. Change 21 (3), $763-809$.

Lee, H., Padmanabhan, V., Whang, S., 1997. Information distortion in a supply chain: the bullwhip effect. Manag. Sci. 43 (4), $546-558$.

Leiponen, A., Helfat, E., 2011. Location, decentralization and knowledge sources for innovation. Organ. Sci. 22 (3), $641-658$.

Leiponen, A., 2001. Why do firms not collaborate? The role of competencies and technological regimes. In: Kleinknecht, A., Mohnen, P. (Eds.), Innovation and Firm Performance. Palgrave, pp. 253-277.

Lhuillery, S., Pfister, E., 2009. R\&D cooperation and failures in innovation projects: empirical evidence from French CIS data. Res. Policy 38 (1), 45-57.

Littler, D., Leverick, F., 1995. Joint ventures for product development: learning from experience. Long Range Plan. $28,58-67$.

Lokshin, B., Hagedoorn, J., Letterie, W., 2011. The bumpy road of technology partnerships: understanding causes and consequences of partnership malfunctioning. Res. Policy 40 (2), 297-308.

Mahoney, J.T., Pandian, J.R., 1992. The resource-based view within the conversation of strategic management. Strateg. Manag. J. 15 (5), $363-380$.

Metters, R., 1997. Quantifying the bullwhip effect in supply chains. J. Oper. Manag. 15 (2), 89-100.

Mitchell, W., Singh, K., 1992. Incumbents' use of pre-entry alliances before expansion into new technical subfields of an industry. J. Econ. Behav. Organ. 18 (3), 347-372.

Mitsuhashi, H., Greve, H., 2009. A matching theory of alliance formation and organizational success: complementarity and compatibility. Acad. Manag. J. 52 (5), 975-995.

Molina-Morales, X., Martinez-Fernandez, T., Torlo, V., 2011. The dark side of trust: the benefits, costs and optimal levels of trust for innovation performance. Long Range Plan. 44, 118-133.

Monjon, S., Waelbroeck, P., 2003. Assessing spillovers from universities to firms: evidence from French firm-level data. Int. J. Ind. Organ. 21 (9), 1255-1270.

Narasimhan, R., Jayaram, J., 1998. Causal Linkages in supply chain management: an exploratory study of North American manufacturing firms. Decis. Sci. 29 (3), 579-605.

Newell, S., Goussevskaia, A., Swan, J., Bresnen, M., Obembe, A., 2008. Interdependencies in complex project ecologies: the case of biomedical innovation. Long Range Plan. 41, 33-54.

Nieto, M.J., Santamaría, L., 2007. The importance of diverse R\&D collaborative networks for the novelty of product innovation. Technovation 27 (6), $367-377$.

OECD, 2005. Oslo manual: Guidelines for Collecting and Interpreting Innovation Data, third ed. Paris.

Parkhe, A., 1993. Strategic alliance structuring, a game theoretic and transaction cost examination of interfirm cooperation. Acad. Manag. J. 36, 794-829.

Park, S., Russo, M., 1996. When competition eclipses cooperation: an event history analysis of joint-venture failure. Manag. Sci. 42 (6), $875-890$.

Parmigiani, A., Rivera-Santos, M., 2011. Clearing a path through the forest: a meta-review of interorganizational relationships. J. Manag. 37, 1108-1136.

Peteraf, M., 1993. The cornerstones of competitive advantage: a resource-based view. Strateg. Manag. J. 14 (3), $179-191$.

Phelps, C., Heidl, R., Wadhwa, A., 2012. Knowledge, networks, and knowledge networks: a review and research agenda. J. Manag. 38 (4), $1115-1166$.

Powell, W.W., Koput, K.W., Smith-Doerr, L., 1996. Interorganizational R\&D collaboration and the locus of innovation: networks of learning in biotechnology. Adm. Sci. Q. 41, 116-145.

Ritala, P., Olander, H., Michailova, S., Husted, K., 2015. Knowledge sharing, knowledge leakage and relative innovation performance: an empirical study. Technovation 35, 22-31.

Roodman, D., 2011. Estimating fully observed recursive mixed-process models with cmp. Stata J. 11 (2), $159-206$.

Rosenzweig, E.D., Roth, A.V., Dean, J.W., 2003. The influence of an integration strategy on competitive capabilities and business performance: an exploratory study of consumer products manufacturers. J. Oper. Manag. 21 (4), 437-456.

Rothaermel, F.T., Deeds, D.L., 2004. Exploration and exploitation alliances in biotechnology: a system of new product development. Strateg. Manag. J. 25 (3), $201-221$.

Rothaermel, F.T., Deeds, D.L., 2006. Alliance type, alliance experience and alliance management capability in high-technology ventures. J. Bus. Ventur. 21, 429-460.

Rowley, T., Behrens, D., Krackhardt, D., 2000. Redundant governance structures: an analysis of structural and relational embeddedness in the steel and semiconductor industries. Strateg. Manag. J. 21 (3), 369-386.

Roy, R., Whelan, R., 1992. Successful recycling through value-chain R\&D collaboration. Long. Range Plan. 25, 62-71.

Salomon, R., Shaver, J.M., 2005. Learning by exporting: new insights from examining firm innovation. J. Econ. Manag. Strategy 14, $431-460$.

Schneider, C., Veugelers, R., 2010. On young highly innovative companies: why they matter and how (not) to policy support them. Ind. Corp. Change 19 (4), 969-1007.

Segarra-Blasco, A., Arauzo-Carod, J.M., 2008. Sources of innovation and industry-university interaction: evidence from Spanish firms. Res. Policy 37 (8), $1283-1295$. 
Skarzynski, P., Gibson, R., 2008. Innovation to the Core, a Blueprint for Transforming the Way Your Company Innovates. Harvard University Press, Cambridge (MA).

Spithoven, A., Clarysse, B., Knockaert, M., 2010. Building absorptive capacity to organize inbound open innovation in traditional industries. Technovation 30, $130-141$.

Srivastava, M.K., Gnyawali, D.R., 2011. When do relational resources matter? Leveraging portfolio technological resources for breakthrough innovation. Acad. Manag. J. 54 (4), 797-810.

StataCorp, 2015. Stata 14 Base Reference Manual. Stata Press, College Station, TX, p. 1330.

Stieglietz, N., Knudsen, Th, Becker, M., 2016. Adaptation and inertia in dynamic environments. Strateg. Manag. J. 37, 1854-1864.

Stuart, T.E., Hoang, H., Hybels, R.C., 1999. Interorganizational endorsements and the performance of entrepreneurial ventures. Adm. Sci. Q. 44 (2), 315-349.

Tasselli, S., Kilduff, M., Menges, J., 2015. The microfoundations of organizational social networks: a review and an agenda for future research. J. Manag. 41 (5), 1361-1387.

Tatarynowicz, A., Sytch, M., Gulati, R., 2016. Environmental demands and the emergence of social structure, technological dynamism and interorganizational network forms. Adm. Sci. Q. 61 (1), 52-86.

Teece, D.J., 1980. Economics of scope and the scope of the enterprise. J. Econ. Behav. Organ. 1, $223-247$.

Tether, B.S., 2002. Who co-operates for innovation, and why: an empirical analysis. Res. Policy 31 (6), $947-967$.

Tidd, J., Bessant, J., Pavitt, K., 2015. Managing Innovation: Integrating Technological, Market and Organizational Change. John Wiley \& Sons, Chichester.

Veugelers, R., Cassiman, B., 2005. R\&D cooperation between firms and universities. Some empirical evidence from Belgian manufacturing. Int. J. Ind. Organ. 23 (5-6), 355-379.

Vickery, S.K., Jayaram, J., Droge, C., Calantone, R., 2003. The effects of an integrative supply chain strategy on customer service and financial performance: an analysis of direct versus indirect relationships. J. Oper. Manag. 21 (5), 523-539.

Von Hippel, E., 1988. The Sources of Innovation. Oxford University Press, Oxford.

Wassmer, U., 2010. Alliance portfolios: a review and research agenda. J. Manag. 36 (1), 141-171.

Woerter, M., Roper, S., 2010. Openness and innovation-home and export demand effects on manufacturing innovation: panel data evidence for Ireland and Switzerland. Res. Policy 39 (1), 155-164.

Wuyts, S., Dutta, S., Stremersch, S., 2012. Portfolios of interfirm agreements in technology-intensive markets: consequences for innovation and profitability. J. Mark. 68 (2), 88-100.

Zucker, L.G., Darby, M.R., Torero, M., 2002. Labor mobility from academe to commerce. J. Labor Econ. 20 (3), $629-660$. 